NUREG/CR-6392

INEL-95/0506

\title{
The Effects of Aging on Compressive Strength of Low-Level Radioactive Waste Form Samples
}

Manuscript Completed: May 1996

Date Published: June 1996

Prepared by

J. W. McConnell, Jr., R. M. Neilson, Jr.

Idaho National Engineering Laboratory Lockheed Idaho Technologies Company Idaho Falls, ID 83415

P. Reed, NRC Project Manager

Prepared for

Division of Regulatory Applications Office of Nuclear Regulatory Research U.S. Nuclear Regulatory Commission Washington, DC 20555-0001

NRC Job Code A6876

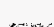

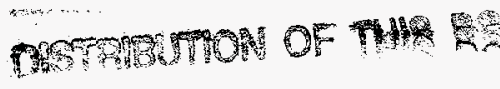




\section{DISCLAIMER}

NUREG/CR-6392 is not a substitute for NRC regulations and compliance is not required. The approaches and/or methods described in this NUREG/CR are provided for information only. Publication of this report does not necessarily constitute NRC approval or agreement with the information contained herein.

\section{DISCLAIMER}

This report was prepared as an account of work sponsored by an agency of the United States Government. Neither the United States Government nor any agency thereof, nor any of their employees, makes any warranty, express or implied, or assumes any legal liability or responsibility for the accuracy, completeness, or usefulness of any information, apparatus, product, or process disclosed, or represents that its use would not infringe privately owned rights. Reference herein to any specific commercial product, process, or service by trade name, trademark, manufacturer, or otherwise does not necessarily constitute or imply its endorsement, recommendation, or favoring by the United States Government or any agency thereof. The views and opinions of authors expressed herein do not necessarily state or reflect those of the United States Government or any agency thereof. 


\section{DISCLAMMER}

Portions of this document may be illegible in electronic image products. Images are produced from the best available original document. 


\section{ABSTRACT}

The Field Lysimeter Investigations: Low-Level Waste Data Base Development Program, funded by the U.S. Nuclear Regulatory Commission (NRC), is (a) studying the degradation effects in organic ion-exchange resins caused by radiation, (b) examining the adequacy of test procedures recommended in the Branch Technical Position on Waste Form to meet the requirements of 10 CFR 61 using solidified ion-exchange resins, (c) obtaining performance information on solidified ion-exchange resins in a disposal environment, and (d) determining the condition of liners used to dispose ion-exchange resins.

Compressive tests were performed periodically over a 12-year period as part of the Technical Position testing. Results of that compressive testing are presented and discussed. During the study, both portland type I-II cement and Dow vinyl esterstyrene waste form samples were tested. This testing was designed to examine the effects of aging caused by self-irradiation on the compressive strength of the waste forms. Also presented is a brief summary of the results of waste form characterization, which had been conducted in 1986, using tests recommended in the Technical Position on Waste Form. The aging test results are compared to the results of those earlier tests.

Job Code A6876—Field Lysimeter Investigations: Low-Level Waste Data Base Development Program 


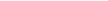




\section{CONTENTS}

DISCLAIMER

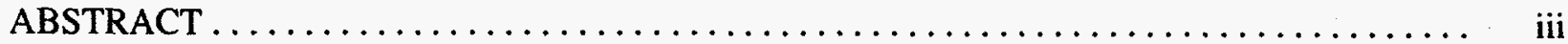

LIST OF FIGURES $\ldots \ldots \ldots \ldots \ldots \ldots \ldots \ldots \ldots \ldots \ldots \ldots \ldots \ldots \ldots \ldots \ldots \ldots \ldots \ldots$

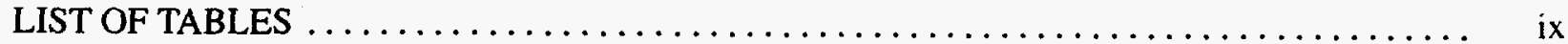

EXECUTIVE SUMMARY $\ldots \ldots \ldots \ldots \ldots \ldots \ldots \ldots \ldots \ldots \ldots \ldots \ldots \ldots \ldots \ldots \ldots$

INTRODUCTION $\ldots \ldots \ldots \ldots \ldots \ldots \ldots \ldots \ldots \ldots \ldots \ldots \ldots \ldots \ldots \ldots \ldots \ldots \ldots \ldots$

MATERIALS AND METHODS USED FOR WASTE FORM COMPRESSIVE

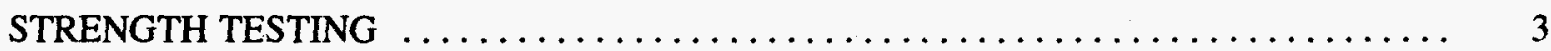

Description of Waste Form Samples $\ldots \ldots \ldots \ldots \ldots \ldots \ldots \ldots \ldots \ldots \ldots \ldots \ldots \ldots$

Branch Technical Position Test Results $\ldots \ldots \ldots \ldots \ldots \ldots \ldots \ldots \ldots \ldots \ldots \ldots$

DESCRIPTION OF AGING TEST RESULTS $\ldots \ldots \ldots \ldots \ldots \ldots \ldots \ldots \ldots \ldots \ldots \ldots$

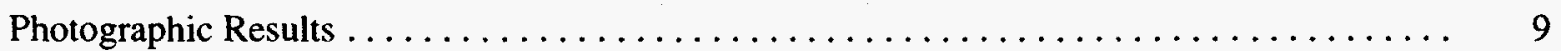

Seven-Year-Old Waste Form Samples $\ldots \ldots \ldots \ldots \ldots \ldots \ldots \ldots \ldots \ldots \ldots \ldots \ldots$

Eight-Year-Old Waste Form Samples $\ldots \ldots \ldots \ldots \ldots \ldots \ldots \ldots \ldots \ldots \ldots \ldots$

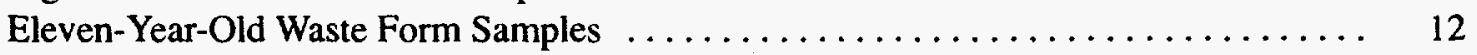

Twelve-Year-Old Waste Form Samples $\ldots \ldots \ldots \ldots \ldots \ldots \ldots \ldots \ldots \ldots \ldots \ldots \ldots \ldots$

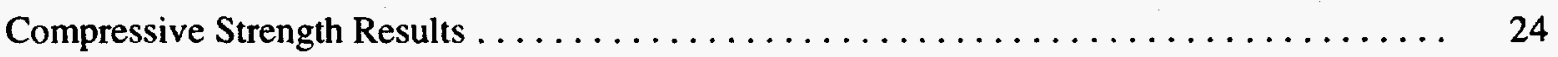

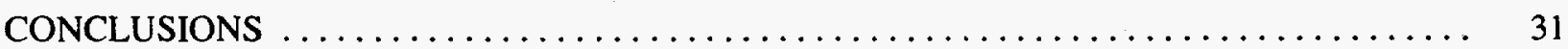

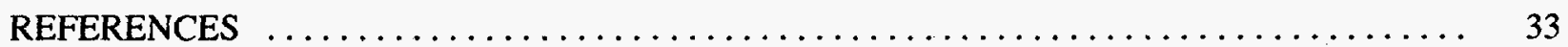




\section{FIGURES}

1. An example of an EPICOR-II prefilter waste form sample $\ldots \ldots \ldots \ldots \ldots \ldots \ldots \ldots \ldots \ldots$

2. Irradiated EPICOR-II waste form sample being placed into polyethylene bag marked with the

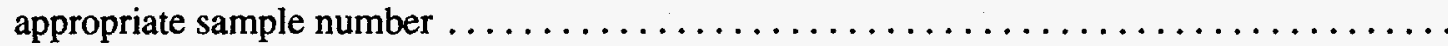

3. Compressive tester frame with EPICOR-II vinyl ester-styrene waste form sample being

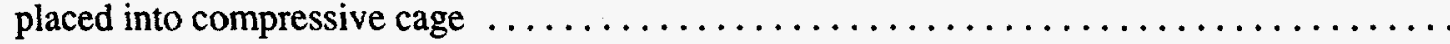

4. Seven-year-old sample $\mathrm{Cl}-23$ organic ion-exchange resin in portland cement after being

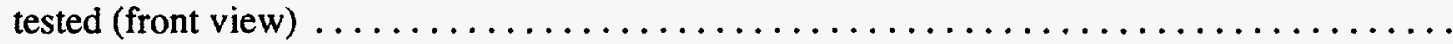

5. Seven-year-old sample $\mathrm{Cl}-23$ organic ion-exchange resin in portland cement after being

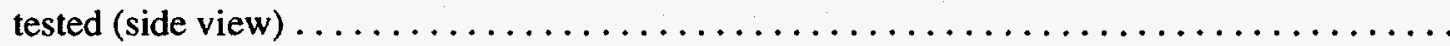

6. Seven-year-old sample $\mathrm{C} 2 \mathrm{~A}-7$ organic/inorganic ion-exchange resin in portland cement

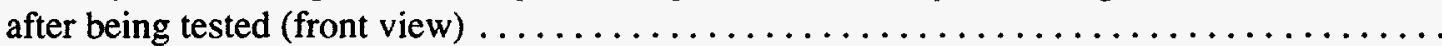

7. Seven-year-old sample $\mathrm{C} 2 \mathrm{~A}-7$ organic/inorganic ion-exchange resin in portland cement

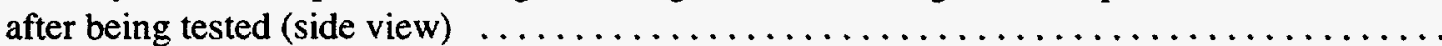

8. Seven-year-old sample D1 A-2 organic ion-exchange resin in vinyl ester-styrene after

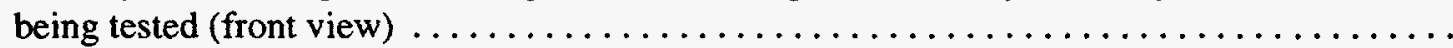

9. Seven-year-old sample D1A-2 organic ion-exchange resin in vinyl ester-styrene after

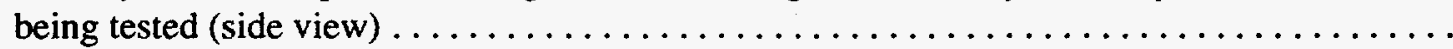

10. Seven-year-old sample D2-27 organic/inorganic ion-exchange resin in vinyl ester-styrene

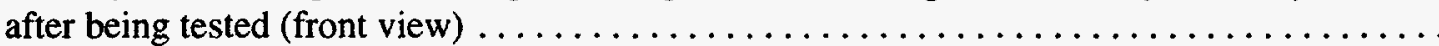

11. Seven-year-old sample D2-27 organic/inorganic ion-exchange resin in vinyl ester-styrene after being tested (side view)

12. Eight-year-old sample $\mathrm{C} 1-26$ organic ion-exchange resin in portland cement before being tested

13. Eight-year-old sample $\mathrm{C} 1-26$ organic ion-exchange resin in portland cement after being tested (front view)

14. Eight-year-old sample $\mathrm{C} 1-26$ organic ion-exchange resin in portland cement after being tested (side view)

15. Eight-year-old sample C2A-6 organic/inorganic ion-exchange resin in portland cement before being tested

16. Eight-year-old sample $\mathrm{C} 2 \mathrm{~A}-6$ organic/inorganic ion-exchange resin in portland cement

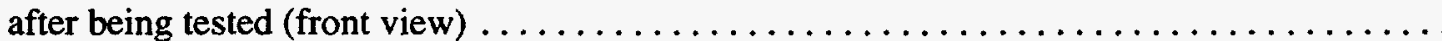

17. Eight-year-old sample C2A-6 organic/inorganic ion-exchange resin in portland cement after being tested (side view) 
18. Eight-year-old sample D1A-1 organic ion-exchange resin in vinyl ester-styrene before being tested

19. Eight-year-old sample D1A-1 organic ion-exchange resin in vinyl ester-styrene after

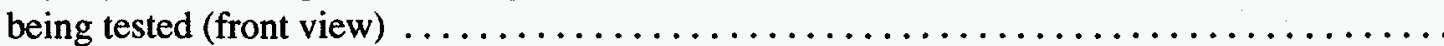

20. Eight-year-old sample D1A-1 organic ion-exchange resin in vinyl ester-styrene after

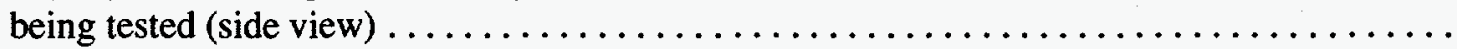

21. Eight-year-old sample D2-35 organic/inorganic ion-exchange resin in vinyl ester-styrene before being tested

22. Eight-year-old sample D2-35 organic/inorganic ion-exchange resin in vinyl ester-styrene

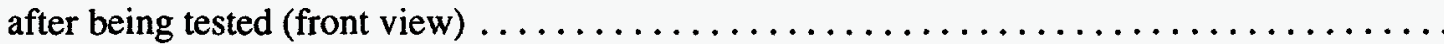

23. Eight-year-old sample D2-35 organic/inorganic ion-exchange resin in vinyl ester-styrene

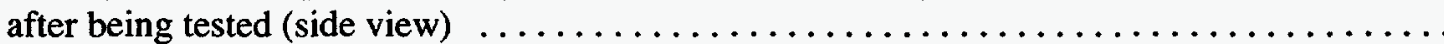

24. Eleven-year-old sample $\mathrm{C} 1-24$ organic ion-exchange resin in portland cement after being tested

25. Eleven-year-old sample C2A-14 organic/inorganic ion-exchange resin in portland cement after being tested

26. Eleven-year-old sample D1 A-29 organic ion-exchange resin in vinyl ester-styrene after being tested

27. Eleven-year-old sample D2-34 organic/inorganic ion-exchange resin in vinyl ester-styrene after being tested

28. Twelve-year-old sample C1-31 organic ion-exchange resin in portland cement before

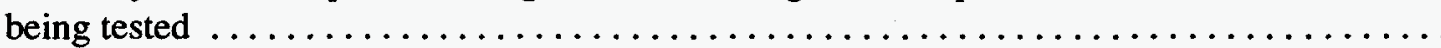

29. Twelve-year-old sample $\mathrm{Cl}-31$ organic ion-exchange resin in portland cement after being tested (front view)

30. Twelve-year-old sample $\mathrm{C} 1-31$ organic ion-exchange resin in portland cement after being tested (side view).

31. Twelve-year-old sample C1-35 organic ion-exchange resin in portland cement before being tested

32. Twelve-year-old sample $\mathrm{Cl}-35$ organic ion-exchange resin in portland cement after

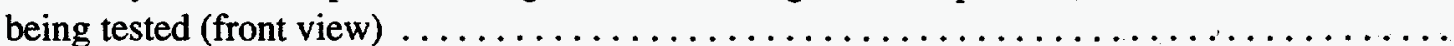

33. Twelve-year-old sample C1-35 organic ion-exchange resin in portland cement after being tested (side view) .

34. Twelve-year-old sample $\mathrm{C} 2 \mathrm{~A}-10$ organic/inorganic ion-exchange resin in portland cement before being tested 
35. Twelve-year-old sample C2A-10 organic/inorganic ion-exchange resin in portland cement

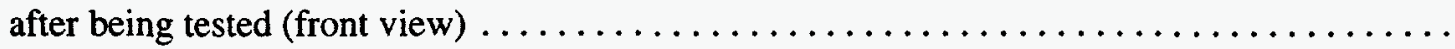

36. Twelve-year-old sample $\mathrm{C} 2 \mathrm{~A}-10$ organic/inorganic ion-exchange resin in portland cement

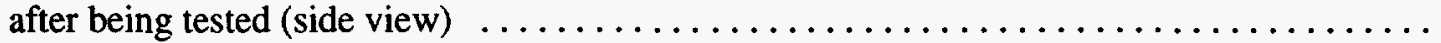

37. Twelve-year-old sample $\mathrm{C} 2 \mathrm{~A}-10$ organic/inorganic ion-exchange resin in portland cement

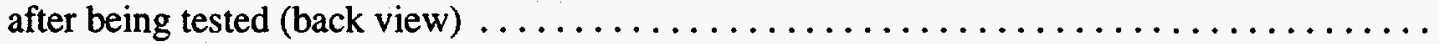

38. Twelve-year-old sample $\mathrm{C} 2 \mathrm{~A}-29$ organic/inorganic ion-exchange resin in portland cement before being tested

39. Twelve-year-old sample C2A-29 organic/inorganic ion-exchange resin in portland cement

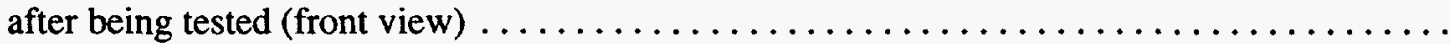

40. Twelve-year-old sample C2A-29 organic/inorganic ion-exchange resin in portland cement after being tested (side view)

41. Twelve-year-old sample D1-13 organic ion-exchange resin in vinyl ester-styrene before being tested

42. Twelve-year-old sample D1-13 organic ion-exchange resin in vinyl ester-styrene after

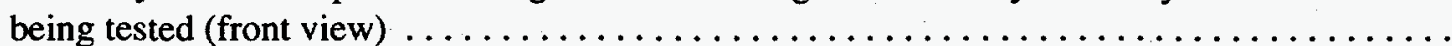

43. Twelve-year-old sample D1-14 organic ion-exchange resin in vinyl ester-styrene before being tested

44. Twelve-year-old sample D1-14 organic ion-exchange resin in vinyl ester-styrene after being tested (front view)

45. Twelve-year-old sample D1-14 organic ion-exchange resin in vinyl ester-styrene after being tested (side view) .

46. Twelve-year-old sample D2-1 organic/inorganic ion-exchange resin in vinyl ester-styrene before being tested

47. Twelve-year-old sample D2-1 organic/inorganic ion-exchange resin in vinyl ester-styrene

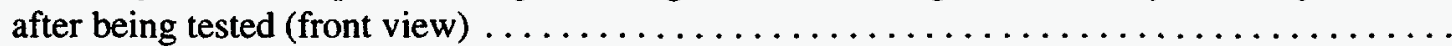

48. Twelve-year-old sample D2-1 organic/inorganic ion-exchange resin in vinyl ester-styrene

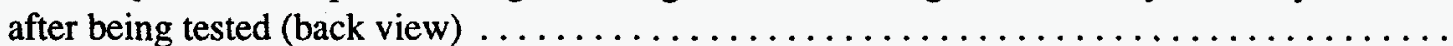

49. Twelve-year-old sample D2-12 organic/inorganic ion-exchange resin in vinyl ester-styrene

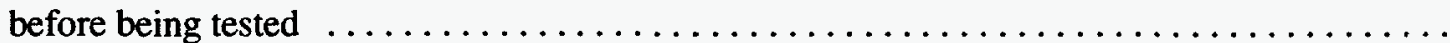

50. Twelve-year-old sample D2-12 organic/inorganic ion-exchange resin in vinyl ester-styrene

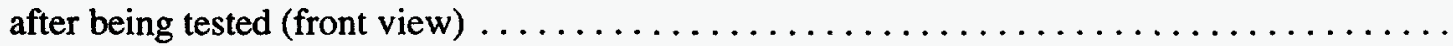

51. Twelve-year-old sample D2-12 organic/inorganic ion-exchange resin in vinyl ester-styrene after being tested (side view)

52. Variation of waste form compressive strength with age caused by self-irradiation and curing 


\section{TABLES}

1. Batch formulations for waste form samples containing EPICOR-II wastes $\ldots \ldots \ldots \ldots \ldots$

2. Activity content of EPICOR-II resin wastes $\ldots \ldots \ldots \ldots \ldots \ldots \ldots \ldots \ldots \ldots \ldots \ldots \ldots$

3. Summary of average compressive strengths of EPICOR-II waste form samples $\ldots \ldots \ldots \ldots$

4. Compressive load test results and radiation dose rates of aged EPICOR-II resin waste form samples

5. Calculated total beta/gamma self-irradiation 300-year end-of-life doses versus gamma external irradiation doses received by EPICOR-II waste form samples in the INEL Advanced Test Reactor gamma irradiation facility in 1985 



\section{EXECUTIVE SUMMARY}

Research is being conducted at the Idaho National Engineering Laboratory on materials from four liners containing organic and inorganic ion-exchange resin under three tasks of the NRC Field Lysimeter Investigations: Low-Level Waste Data Base Development Program.

In the first task, Resin Degradation, the changes caused by contained radioactivity were observed in the ion-exchange resin from two disposal liners. Three resin samplings were made over a period of 6 years. Results of this study were presented in three NUREG/CR reports.

For the second task, Resin Solidification, portland type I-II cement and vinyl ester-styrene (VES) waste form samples incorporating ionexchange resin waste from disposal liners were subjected to the tests specified in the Low-Level Waste Management Branch's "Technical Position on Waste Form" issued by the Nuclear Regulatory Commission. Waste form performance data were obtained and reported in two NUREG/CR reports as a result of that work. Further testing to study aging effects caused by self-irradiation in storage was performed and is the subject of this report.

The third task, Field Testing, is an ongoing examination of the effect of disposal environments on solidified ion-exchange resin wastes. The purpose of this task, using two field lysimeter arrays, is to expose samples of ionexchange resin (which were solidified during the Resin Solidification task) to the actual physical, chemical, and microbiological conditions of a disposal environment.

The ion-exchange resins, which were solidified with both portland type I-II cement and VES, were used in an extension of the Resin Solidification work. These waste form samples have been compressive load-tested on a periodic basis over a span of 12 years. The purpose of this study was to examine the effects over time of self-irradiation on the compressive strength of the solidified waste form samples. The resulting compressive strength data are compared to waste form performance information obtained during the earlier Technical Position testing and are used to evaluate aging of the waste form samples. These data indicated a general increase in compressive strength of both waste form types with time to a point at which the strength of the VES waste form samples began to drop, while the strength of the cement waste form samples stabilized. A comparison to test results from 300-year end-of-life externally irradiated waste form samples indicates that the strength of the cement waste form samples will also decrease with a further increase in dose. 


\section{The Effects of Aging on Compressive Strength of Low-Level Radioactive Waste Form Samples}

\section{INTRODUCTION}

The 28 March 1979 accident at Three Mile Island Unit 2 released approximately 560,000 gal of contaminated water to the auxiliary and fuel handling buildings. The water was decontaminated using a demineralization system called EPICOR-II developed by Epicor, Inc. ${ }^{\text {a }}$ The contaminated water was cycled through three stages of organic and inorganic ion-exchange media. The first stage of the system was designated the prefilter, and the second and third stages were called demineralizers. After the filtration process, the ion-exchange media in $\mathbf{5 0}$ of the prefilters contained radionuclides in concentrations greater than the U.S. Nuclear Regulatory Commission (NRC) recommended limits for lowlevel wastes. Those prefilters were transported to the Idaho National Engineering Laboratory for interim storage before final disposal. A special overpack (high-integrity container) was developed during that storage period to dispose the prefilters at a commercial disposal facility in the State of Washington. As part of the EPICOR and Waste Research and Disposition Program funded by the U.S. Department of Energy, 46 prefilters were disposed, while four were retained for research purposes. Those prefilters used in the research were stored in temporary storage casks and were later disposed at the Radioactive Waste Management Complex at the Idaho National Engineering Laboratory (INEL).

Under the EPICOR and Waste Research and Disposition Program, continuing research has been conducted by the INEL on materials from those four EPICOR-II prefilters. ${ }^{1,2}$ That work is

a. References herein to any specific commercial product, process, or service by trade name, trademark, manufacturer, or otherwise, does not necessarily constitute or imply its endorsement, recommendations, or favoring by the United States Government or any agency thereof. now funded and directed by the NRC as part of the Field Lysimeter Investigations: Low-Level Waste Data Base Development Program. Three studies were initiated on organic ion-exchange resins from selected prefilters: (a) the resins were examined to measure radiation degradation, (b) tests were performed to characterize solidified ion-exchange resin waste form samples, and (c) experiments are being conducted to field-test solidified wastes using lysimeters.

The Resin Degradation studies examined the radiation degradation caused by contained radionuclides to the organic ion-exchange resin from EPICOR-II prefilters PF-8 and PF-20. Three resin samplings were made over a period of 6 years. Those examinations were completed, and the results were published in three NUREG/CR reports.

In the tests performed in the Resin Solidification task, the EPICOR-II wastes were solidified from two of those prefilters, PF-7 and PF-24, using portland type I-II cement and VES, a proprietary solidification agent developed and supplied by the Dow Chemical Company. The formulations used for the immobilization of EPICOR-II wastes were developed to produce waste forms meeting the regulatory requirements of 10 CFR 61, "Licensing Requirements for Land Disposal of Radioactive Wastes." 3 The NRC LowLevel Waste Management Branch, in its "Technical Position on Waste Form"4 (BTP), which has been replaced by the BTP Revision 1,5 provides guidance to waste generators on waste form test methods and acceptance criteria for compliance with the waste form requirements of 10 CFR 61. In that study, EPICOR-II waste form samples were subjected to the recommended NRC test procedures to (a) evaluate the test procedures, (b) ensure compliance with the BTP stability requirements, and (c) characterize the waste forms. The solidification and testing 
studies were completed and reported in References 6 through 9 .

In the Field Testing task, waste form samples fabricated under the Resin Solidification task are being field-tested at two locations using lysimeters. Experiments were installed at Argonne National Laboratory-East and Oak Ridge National Laboratory to study the effects of disposal environments on those waste form samples. The objectives of the Field Testing task are to (a) examine the performance of the waste form samples in typical low-level waste disposal environments, (b) compare field results with bench leach studies and with Department of Energy Special Waste Program field test results, and (c) develop a low-level radioactive waste field leach-rate data base for use in performance assessment source term calculations.

A number of the waste form samples solidified as part of the Resin Solidification task were used in an extension of that study. The purpose of this work was to examine the effects over time of selfirradiation on the compressive strength of these waste form samples. Cement and VES solidified resin waste form samples were compressivetested on a periodic basis over a span of 12 years. The results of these tests were initially given in an abbreviated form in annual reports (References 10 through 12 ). These data and comparisons to waste form sample performance information obtained during earlier BTP testings are presented in greater detail in this report along with an evaluation of the aging behavior of the waste form samples. 


\section{MATERIALS AND METHODS USED FOR WASTE FORM SAMPLE COMPRESSIVE STRENGTH TESTING}

Solidified waste form samples containing EPICOR-II ion-exchange resin waste were periodically compressive-load-tested over a 12-year time span. The intent of the testing was to evaluate the effects of typical storage and disposal selfirradiation conditions on aging of the waste form samples through the change in compressive strength over time.

This aging study included compressive strength testing of 20 waste form samples at four different times over a period from 7 years to 12 years after fabrication. These samples were stored close-packed in a shielded drum throughout that period. The primary expected mechanism for degradation under these storage conditions is self-irradiation. At years 7,8, and 11, one sample of each of the four waste form types was compressive-tested. At year 12, two samples of each type were tested. Samples that failed in a brittle manner were tested to actual failure; the compressive strength of ductile samples was determined by the maximum load supported during testing.

Waste form samples were compressive-tested per ASTM C39 13 using a Tinuis Olsen 60,000-lb testing machine. That machine was normally calibrated prior to this testing. The ASTM test method was used for all samples tested in this aging study. Testing utilized fewer samples than the ten recommended by ASTM C39 due to limitations on the number of samples available. Samples with mass and contact dose readings similar to those tested in 1984-85 were used. ${ }^{6,7}$

This report contains data from 12 years of compressive strength tests on the solidified EPICOR-II resin waste form samples. These tests were performed in addition to those which were a part of earlier BTP testing of these waste forms. The data from those earlier tests are used to supplement and compare with these aging data. More detail of those earlier tests is provided in References 6 through 8 .

\section{Description of Waste Form Samples}

Waste form samples used in the aging tests were composed of solidified EPICOR-II prefilter resin wastes. Two waste types were solidified. One was a mixture of synthetic organic ion-exchange resins (phenolic cation, strong acid cation, and strong base anion resins) from prefilter PF-7, and the other was a mixture of synthetic organic ion-exchange resins (strong acid cation and strong base anion resins) with an inorganic zeolite from prefilter PF-24.

Portland type I-II cement and VES were used to solidify both types of resin wastes. In all, 267 waste form samples were prepared by combining the resin waste with either cement or VES and allowing the mixture to harden in polyethylene molds $4.8 \mathrm{~cm}$ in diameter and $10.2 \mathrm{~cm}$ high. Four batches of waste form samples were prepared using cement, two batches for each waste type (PF-7 and PF-24). Also, four batches of waste form samples were prepared using VES, two batches for each waste type. Table 1 gives the formulations used. The completed waste form samples had an average dimension of $4.8 \mathrm{~cm}$ in diameter and $7.6 \mathrm{~cm}$ high $\left(137.5 \mathrm{~cm}^{3}\right.$ ) (Figure 1).

Aliquots (0.1 to $0.3 \mathrm{~g}$ each) of dried EPICOR-II resin wastes were analyzed by gamma spectroscopy and $\mathrm{Sr}-90$ analysis to determine the radionuclide contents. Prefilter PF-7 contained 5\% Sr-90, while prefilter PF-24 contained about $1 \% \mathrm{Sr}-90$. Of the other radionuclides in those wastes, Cs-137 and Cs-134 are the major constituents, with traces of Co-60 and Sb-125 included. The average resin activity contents for these wastes are given in Table 2 . 
Table 1. Batch formulations for waste form samples containing EPICOR-II wastes.

\begin{tabular}{llcccccc}
\hline & \multicolumn{7}{c}{ Formulation weight percentage } \\
\cline { 2 - 7 } & $\begin{array}{c}\text { Waste } \\
\text { type }\end{array}$ & $\begin{array}{c}\text { As-received } \\
\text { waste }\end{array}$ & $\begin{array}{c}\text { Added } \\
\text { water }\end{array}$ & $\begin{array}{c}\text { Decanted } \\
\text { waste total }^{\mathrm{b}}\end{array}$ & $\begin{array}{c}\text { Portland } \\
\text { type I-II } \\
\text { cement }\end{array}$ & $\begin{array}{c}\text { Additional } \\
\text { water }\end{array}$ & $\begin{array}{c}\text { Vinyl } \\
\text { ester-styrene }\end{array}$ \\
\hline C1 & PF-7 & 15.6 & 8.5 & 24.1 & 62.7 & 13.2 & - \\
C1A & PF-7 & 15.6 & 8.5 & 24.1 & 62.7 & 13.2 & - \\
C2A & PF-24 & 16.8 & 7.2 & 24.0 & 62.5 & 13.5 & - \\
C2B & PF-24 & 16.5 & 7.0 & 23.5 & 61.4 & 15.1 & - \\
D1 & PF-7 & 40.9 & 20.3 & 61.3 & - & - & 38.7 \\
D1A & PF-7 & 38.9 & 22.6 & 61.5 & - & - & 38.5 \\
D2 & PF-24 & 43.1 & 18.3 & 61.4 & - & - & 38.6 \\
D2A & PF-24 & 34.9 & 14.9 & 49.8 & - & - & 50.2
\end{tabular}

a. Does not include catalyst and promoter, which constitutes a total of approximately $1 \mathrm{wt} \%$ of VES waste form samples.

b. Decanted waste total is the as-received waste plus added water.

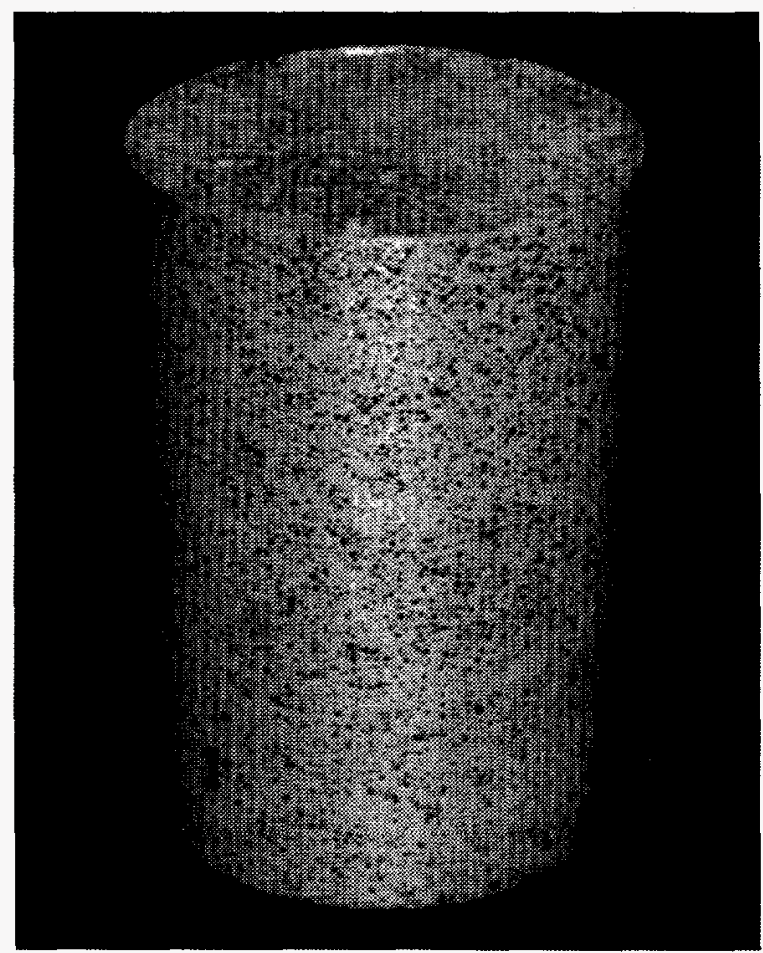

Figure 1. An example of an EPICOR-II prefilter waste form sample.

\section{Branch Technical Position Test Results}

Radioactive EPICOR-II waste form samples were characterized at the INEL in 1986 by testing in accordance with recommendations in the BTP to determine the presence of any free-standing liquid, as-prepared compressive strength, and homogeneity. Typical handling and testing situations with these highly radioactive waste form samples are shown in Figures 2 and 3. During the tests, no free-standing liquid was observed on any of the waste form samples. The compressive strengths of all the as-prepared waste form samples tested exceeded $500 \mathrm{psi}$, the minimum recommended by Appendix A of the BTP Revision 1 for cement waste forms. The average compressive strengths are presented in Table 3 . Those data are summarized from results given in Reference 7 . The high compressive strengths and the appearance of the waste form samples after failure during this BTP testing indicated that the waste forms were homogeneous. 
Table 2. Activity content of EPICOR-II resin wastes.

\begin{tabular}{lll}
\hline Waste type & Nuclide & $\begin{array}{c}\text { Activity content }{ }^{\mathrm{a}} \pm 1 \sigma \\
\text { (Ci/g dry resin) }\end{array}$ \\
\hline PF-7 & Cs-134 & $7.73 \mathrm{E}-05 \pm 2.83 \mathrm{E}-07$ \\
& Cs-137 & $1.17 \mathrm{E}-03 \pm 9.90 \mathrm{E}-05$ \\
& Sr-90 & $6.92 \mathrm{E}-05 \pm 7.21 \mathrm{E}-06$ \\
PF-24 & Cs-134 & $3.30 \mathrm{E}-04 \pm 5.80 \mathrm{E}-05$ \\
& Cs-137 & $4.99 \mathrm{E}-03 \pm 3.04 \mathrm{E}-04$ \\
& Sr-90 & $1.18 \mathrm{E}-05 \pm 6.36 \mathrm{E}-07$
\end{tabular}

a. Cs-134 and -137 as of September 20, 1983; Sr-90 as of October 25, 1983.

Environmental tests were also conducted on the waste form samples in accordance with BTP recommendations to determine thermal stability, leachability, immersion stability, radiation stability, leachability after irradiation, and biodegradability. The results of those tests are summarized in the following paragraphs.

No thermal instability was noted in testing. Average compressive strength test data are given in Table 3 for the thermally cycled waste form samples. All waste form samples had compressive strengths after thermal cycling well in excess of the recommended 500 psi.

The cement and VES waste form samples containing wastes from both prefilters PF-7 and PF-24 were found to be resistant to leaching. All waste form samples tested had leachability indexes greater than 6.0, as required by the BTP.

Immersion stability was determined by testing the compressive strength of waste form samples that had been immersed for 90 days in seawater or in deionized water. All samples exhibited strengths well above the recommended 500 psi, as shown in Table 3.

In the radiation degradation test, the total gamma irradiation dose received by the waste form samples was larger than the total dose of beta and gamma radiation that waste forms would have received through self-irradiation by the end of 300 years. All irradiated samples had compressive strengths far in excess of the recommended 500 psi (Table 3).

Even though leachability after irradiation testing is not required by the BTP, tests were conducted. All leachability indexes were above the value of 6.0 recommended by the BTP. ${ }^{7}$

VES and cement waste form samples were examined for biodegradation by placing them in nutrient-rich media containing fungi or bacteria. The VES waste form samples supported fungal growth, but not bacterial growth. The cement waste form samples were not affected by and did not support either bacterial or fungal growth. Only cement waste form samples from prefilter PF-7 were subjected to compressive strength tests after exposure to microbial attack. The results are given in Table 3. All samples had compressive strengths far in excess of the recommended 500 psi.

A complete description of waste form sample manufacture is given in Reference 6; testing of EPICOR-II waste form samples, according to the recommendations of the BTP, is further described in References 7 through 9. 
Materials and Methods

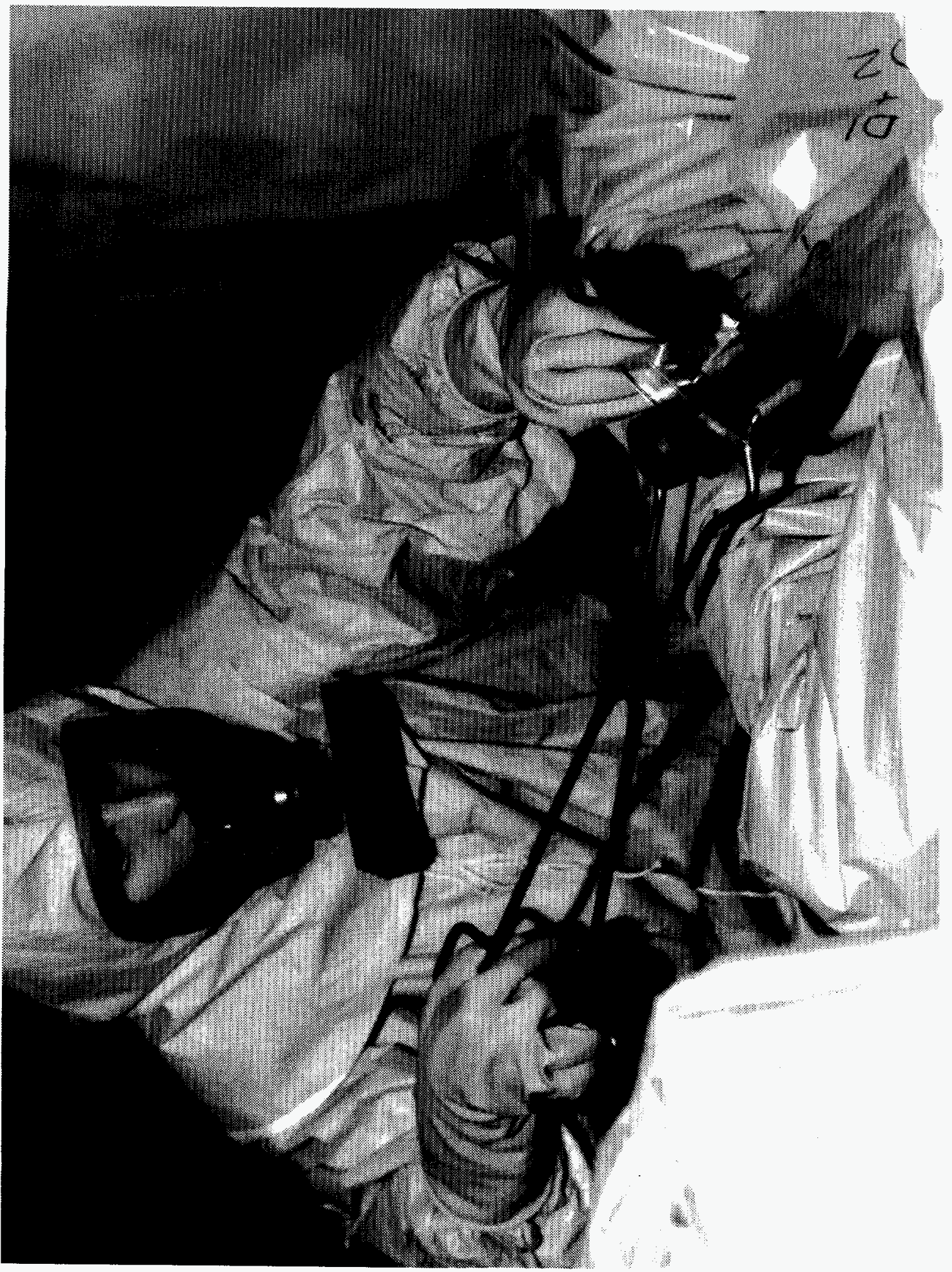

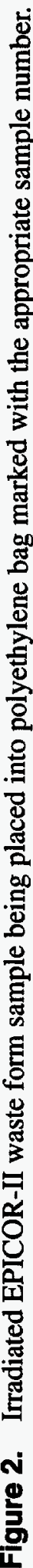




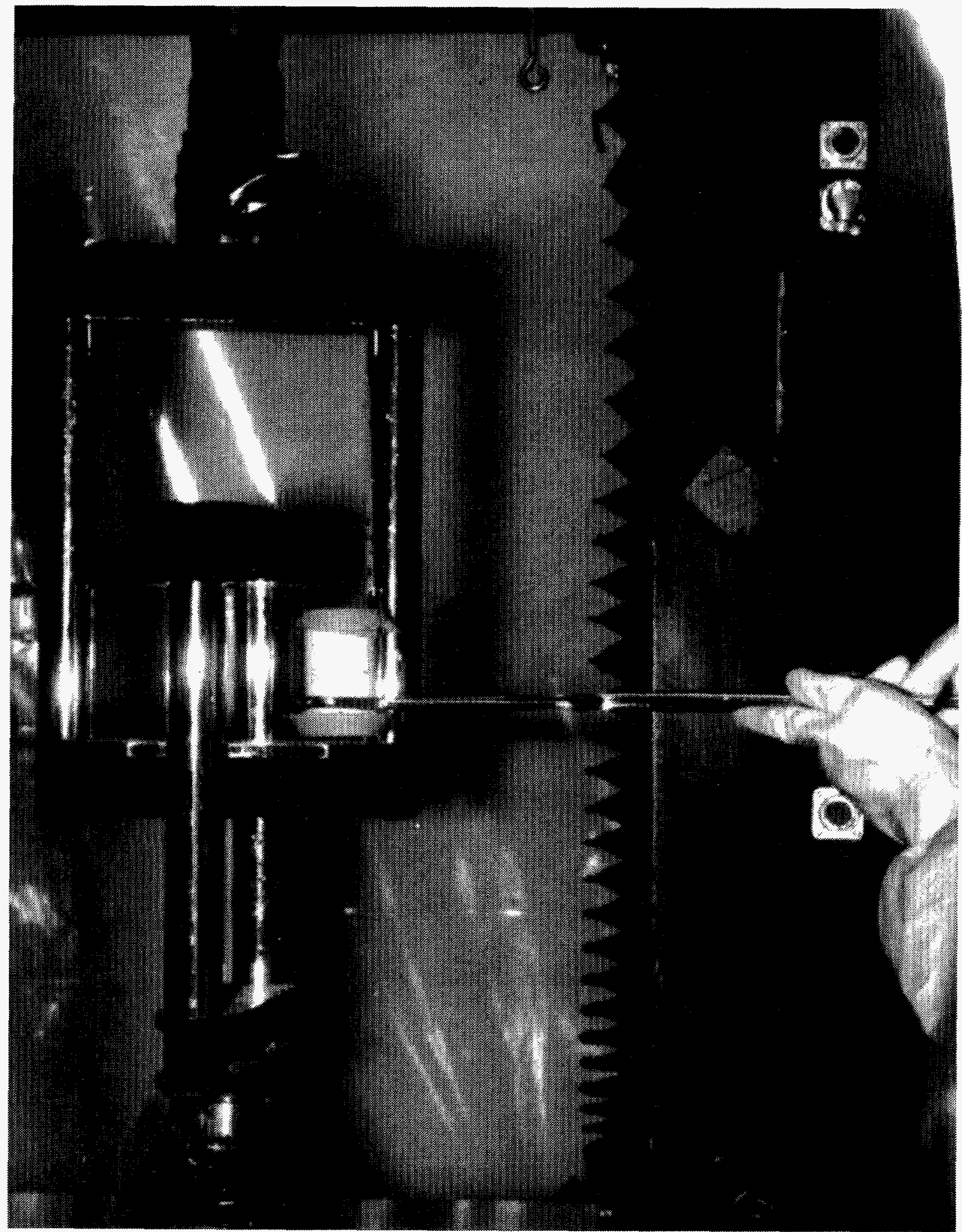

Figure 3. Compressive tester frame with EPICOR-II vinyl ester-styrene waste form sample being placed into compressive cage. 
Materials and Methods

Table 3. Summary of average compressive strengths of EPICOR-II waste form samples. ${ }^{7}$

\begin{tabular}{lccccc}
\hline & \multicolumn{5}{c}{$\begin{array}{c}\text { Average compressive strengths } \pm 1 \sigma \\
\text { (psi) }\end{array}$} \\
\cline { 2 - 6 } $\begin{array}{l}\text { Waste form } \\
\text { sample type }\end{array}$ & As-prepared & $\begin{array}{c}\text { Thermal } \\
\text { cycled }\end{array}$ & $\begin{array}{c}\text { Immersion } \\
\text { tested }\end{array}$ & $\begin{array}{c}\text { Radiation } \\
\text { stability }\end{array}$ & Biodegradability \\
\hline C1, C1A & $2,930 \pm 480$ & $4,740 \pm 90$ & $2,960 \pm 780$ & $3,640 \pm 1,440$ & $2,260 \pm 740$ \\
C2A, C2B & $3,620 \pm 720$ & $5,670 \pm 650$ & $3,850 \pm 1,200$ & $3,310 \pm 1,710$ & - \\
D1, D1A & $2,900 \pm 150$ & $2,770 \pm 330$ & $2,770 \pm 300$ & $1,930 \pm 560$ & - \\
D2 & $3,580 \pm 190$ & $4,060 \pm 70$ & $3,270 \pm 320$ & $2,420 \pm 810$ & - \\
& \\
C = Portland type I-II cement; D = vinyl ester-styrene. \\
1 = All organic ion-exchange resins (prefilter PF-7); $2=$ organic/inorganic ion-exchange resins (prefilter PF-24). \\
Blank = first batch; A = second batch; B = third batch. \\
\hline
\end{tabular}




\section{DESCRIPTION OF AGING TEST RESULTS}

In this section, "before" and "after" photographs of the 20 compressive-tested waste form samples are presented and described. The compressive strengths exhibited during testing of these waste form samples is tabulated. These data are also plotted by sample age and compared to as-cast, immersion-tested, and irradiation-tested waste form compressive strengths.

\section{Photographic Results}

Seven-Year-Old Waste Form Samples. On June 28, 1990, four 7-year-old waste form samples were compressive-tested per ASTM C39, ${ }^{13}$ using the Tinuis Olsen testing machine, which was calibrated on June 21,1990 . The samples were tested dry using poured epoxy leveling caps. One sample of each waste type (all organic and organic/inorganic) in each binder (portland cement and VES) were tested. The initial test results were presented in Reference 10 .

The cement samples failed in a brittle manner, in shear on a near-vertical plane with some flaking. The VES samples flowed in response to the applied load with significant bulging near the center of the cylinders. The VES samples were ductile, and compressive strength was calculated from the maximum supported load. Cracks formed in the central bulged area of the VES samples. The tested samples are shown in Figures 4 through 11.

The cement sample containing all organic resin, $\mathrm{C1}-23$, is shown in Figures 4 and 5, taken at about 90 degrees from each other after being tested. A large portion of the side of the sample has flaked off, and surfacial cracks are visible near the flaking (Figure 4). Also evident are a number of small surface air bubbles and one large bubble. This sample exhibited typical brittle fracture failure.

The cement sample containing organic/inorganic resin, C2A-7, is shown in Figures 6 and 7, taken at about 90 degrees from each other after being tested. This sample exhibited a small amount of flaking with a few surface cracks visible in Figure 6. Several large casting air bubbles are visible, along with a number of small ones. This sample exhibited typical brittle fracture failure.

The VES sample containing all organic resins, D1A-2, is shown in Figures 8 and 9, taken at about 90 degrees from each other after being tested. This sample had a distinct bulge at the midpoint, which is more evident in Figure 8 than in Figure 9. Cracking is barely visible in the lower right of the sample (Figure 8 ), seen as a diagonal line at the edge of the smooth surface. The surface has become rough with protruding resin beads. This sample exhibited a ductile compressive failure.

The VES sample containing organic/inorganic resin, D2-27, is shown in Figures 10 and 11, taken at about 90 degrees from each other after being tested. This sample had a distinct bulge at the midpoint as seen in both figures. Cracking is quite evident in both views and consists of large, angled fractures. There was some surface roughness caused by protruding resin beads. This sample exhibited a ductile compressive failure.

These waste form samples have been stored in shielded drums throughout the project. Dose measurements indicate that the samples experienced a total beta/gamma dose of $0.37 \times 10^{6}$ to $1.83 \times 10^{6} \mathrm{rad}$ during storage. The self-irradiation dose caused serious embrittlement of the polyethylene sample containers, which were beginning to crack.

Eight-Year-Old Waste Form Samples On December 13, 1991, four 8-year-old waste form samples were compressive-tested per ASTM C39 $9^{13}$ using the same Tinuis Olsen testing machine, which was calibrated on June $21,1990$. The samples were tested using poured epoxy leveling caps. One sample of each type of ionexchange resin waste type (all organic and organic/inorganic) in each solidification agent (portland cement and VES) were tested. The initial test results were presented in Reference 11. 


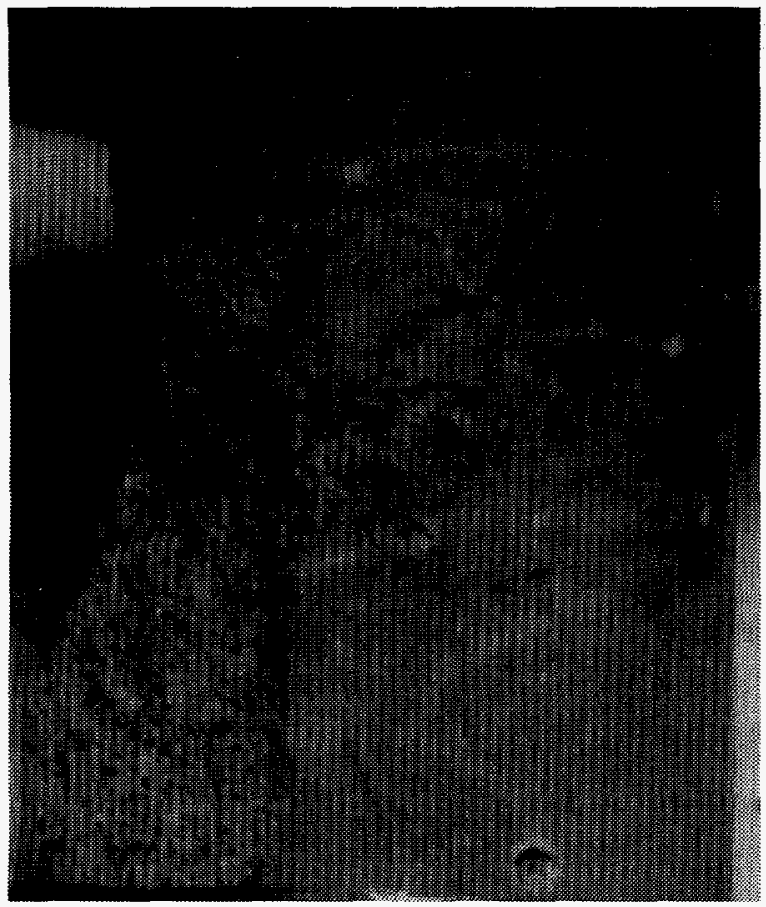

Figure 4. Seven-year-old sample C1-23 organic ion-exchange resin in portland cement after being tested (front view).

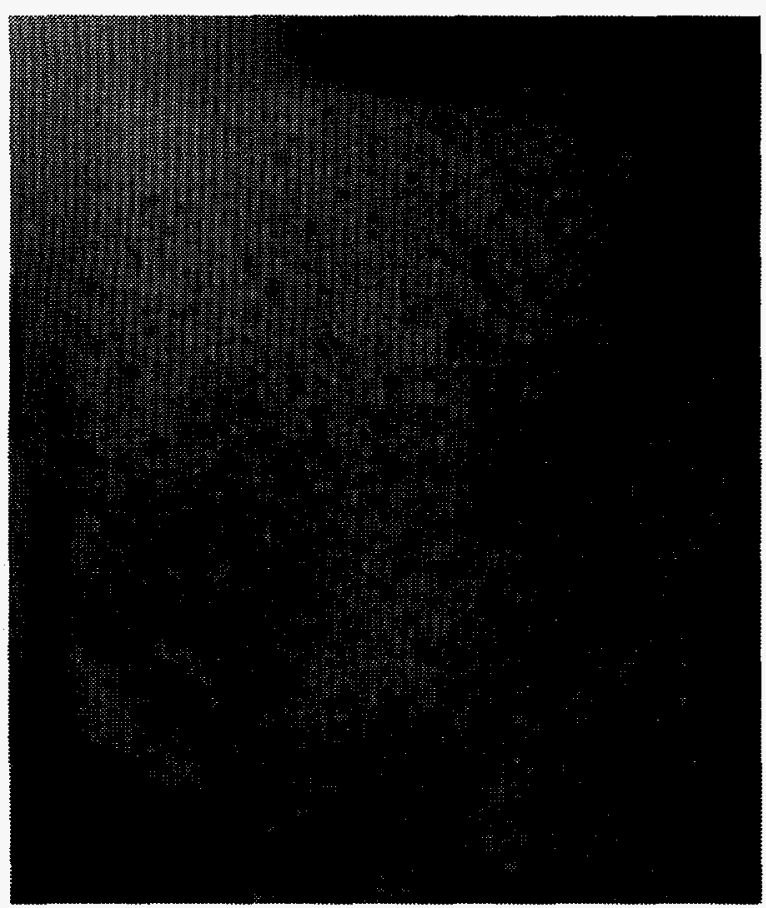

Figure 5. Seven-year-old sample C1-23 organic ion-exchange resin in portland cement after being tested (side view).

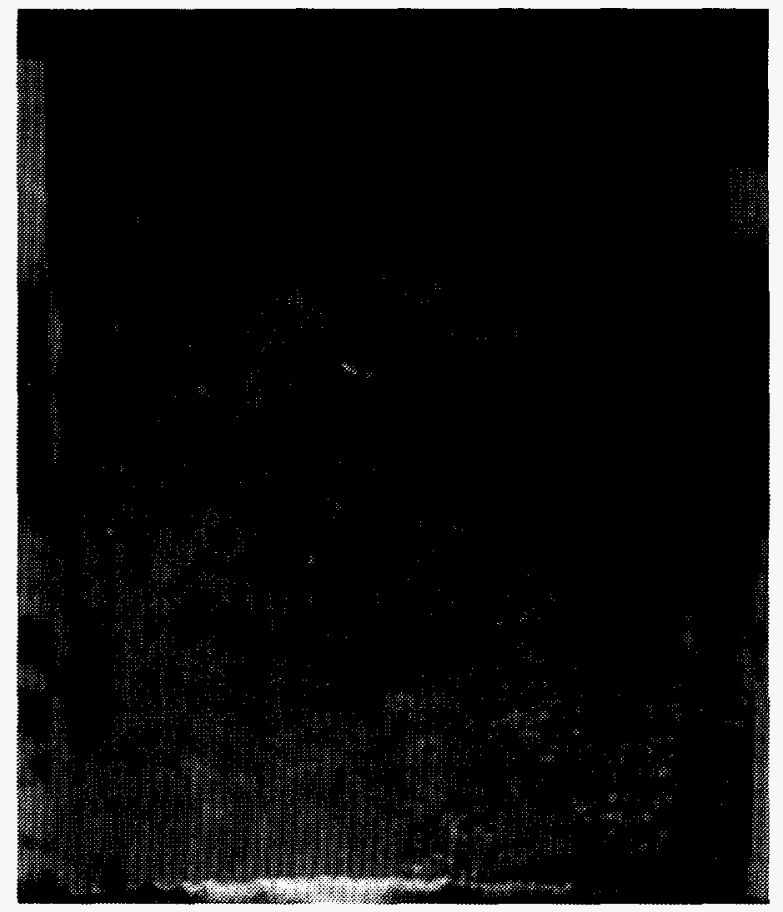

Figure 6. Seven-year-old sample C2A-7 organic/inorganic ion-exchange resin in portland cement after being tested (front view).

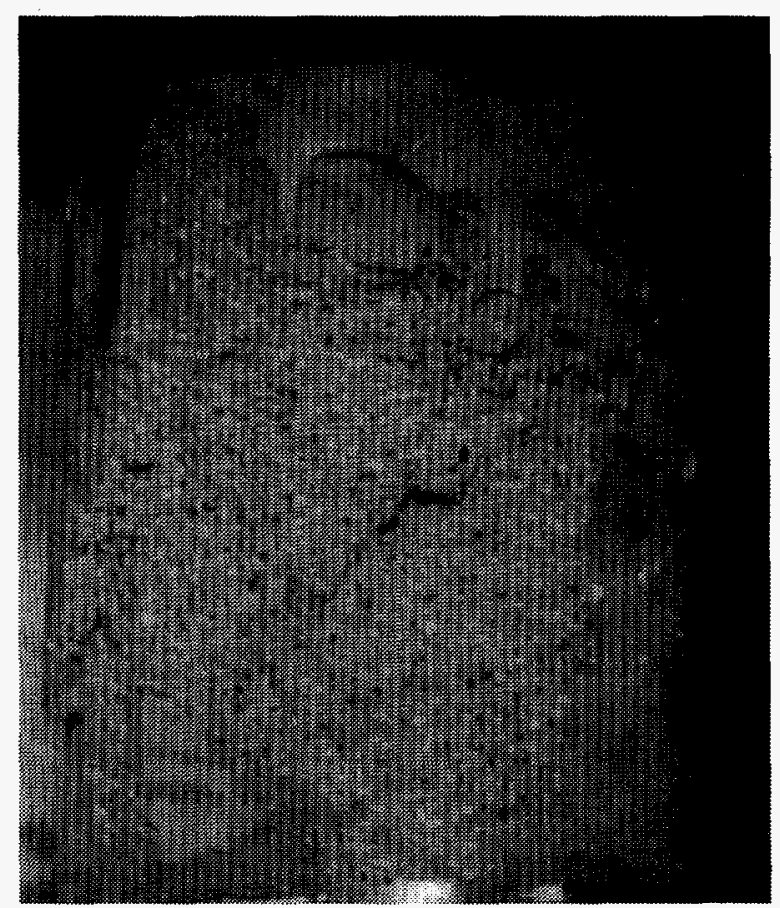

Figure 7. Seven-year-old sample C2A-7 organic/inorganic ion-exchange resin in portland cement after being tested (side view). 


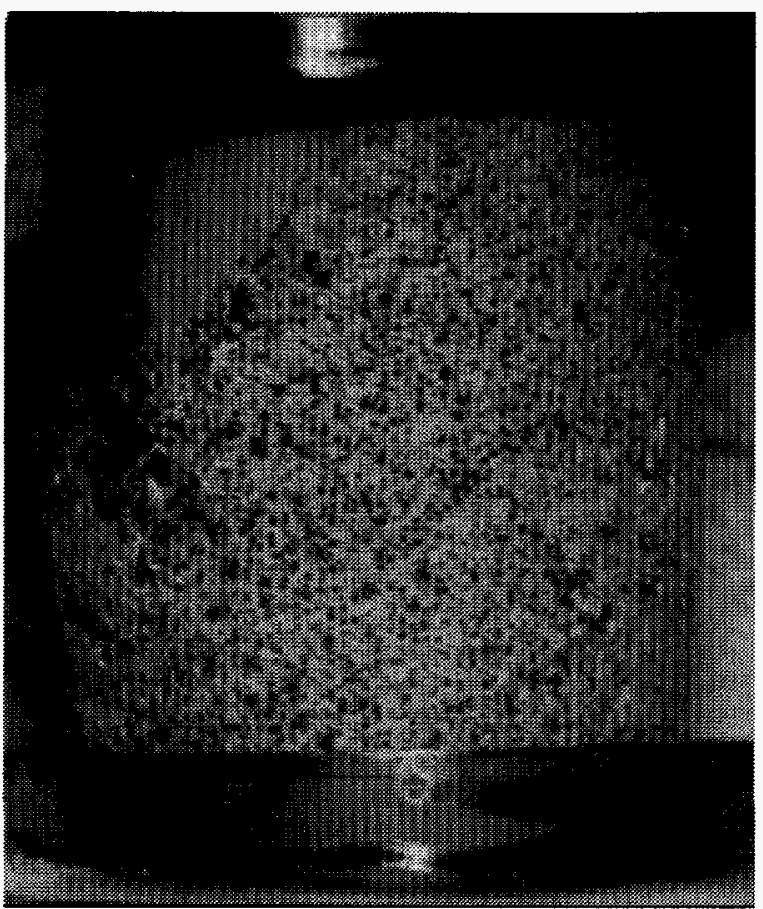

Figure 8. Seven-year-old sample D1A-2 organic ion-exchange resin in vinyl ester-styrene after being tested (front view).

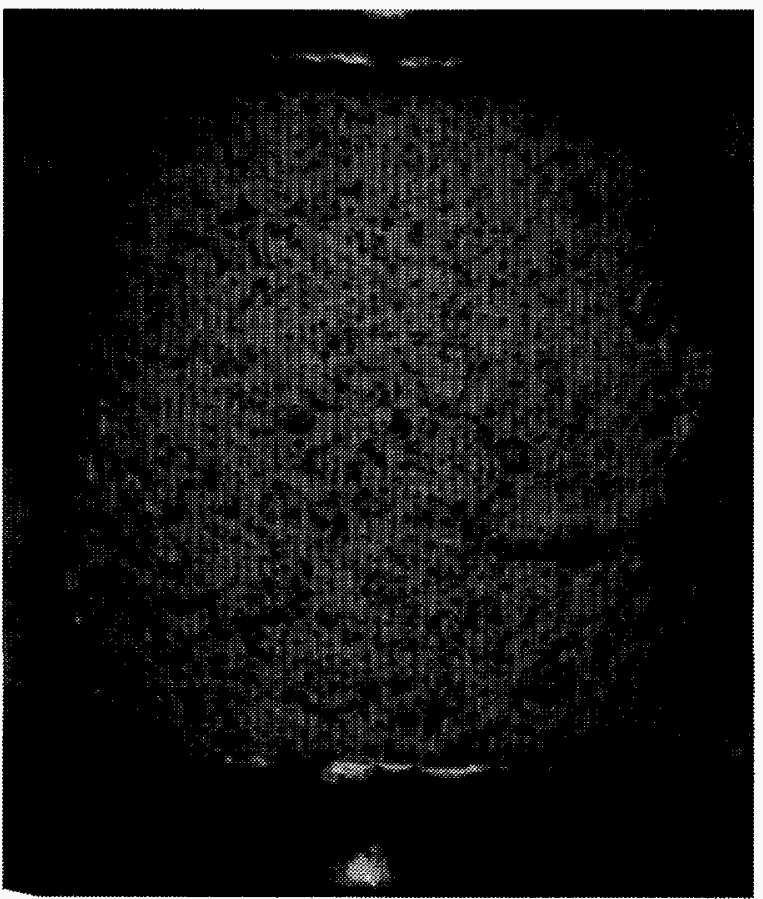

Figure 9. Seven-year-old sample D1A-2 organic ion-exchange resin in vinyl ester-styrene after being tested (side view).

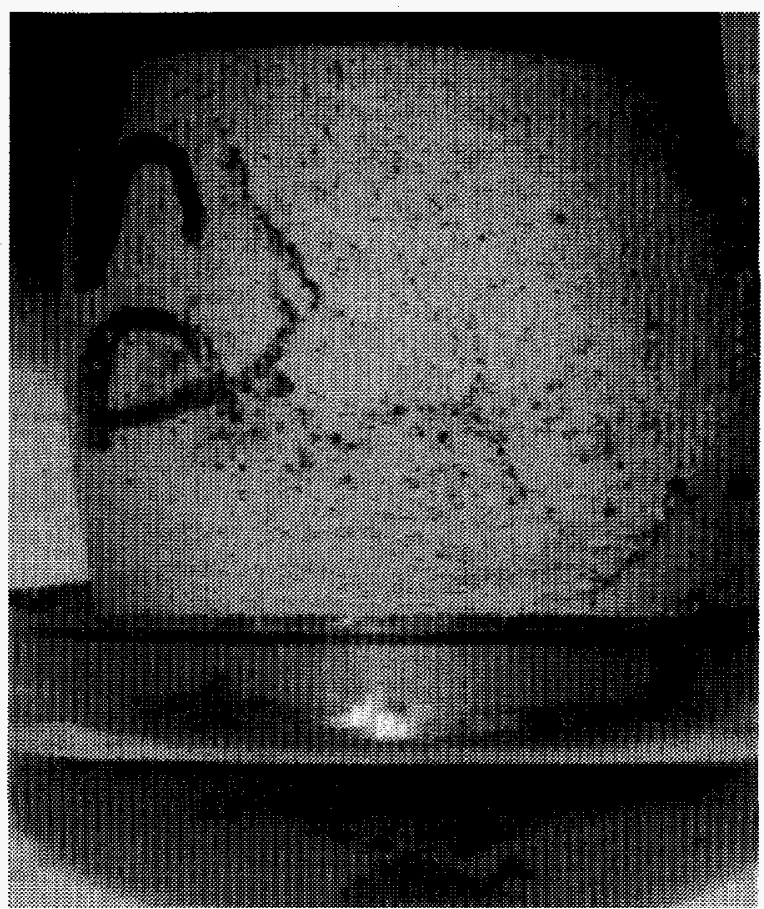

Figure 10. Seven-year-old sample D2-27 organic/inorganic ion-exchange resin in vinyl ester-styrene after being tested (front view).

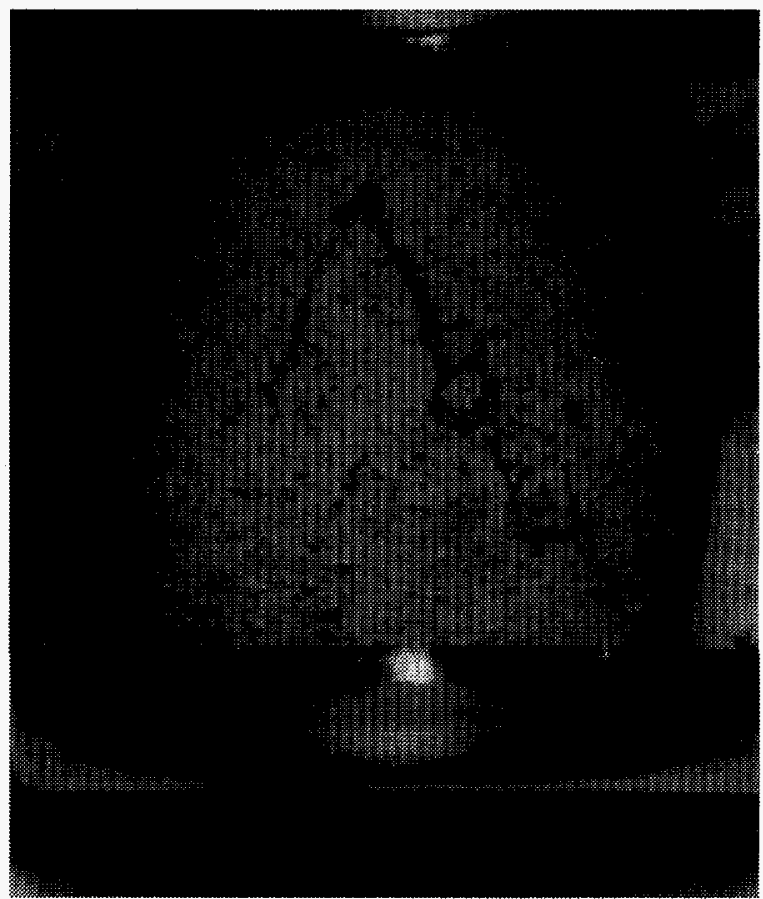

Figure 11. Seven-year-old sample D2-27 organic/inorganic ion-exchange resin in vinyl ester-styrene after being tested (side view) 
The cement samples broke in the typical, brittle vertical cracking pattern with some flaking. The VES samples bulged in the center of the cylinders. Failure cracks formed within the bulging center area. The VES samples appeared to be ductile. The tested samples are shown in Figures 12 through 23.

The cement sample containing all organic resin, C1-26, is shown in Figures 12 through 14. In Figure 12 , the sample is shown before being tested. Figures 13 and 14 were taken at about 90 degrees from each other after being tested. A large piece of the sample flaked, and numerous other smaller pieces are seen adjacent to it (Figure 12). A number of small air bubbles can be seen on the sample surface. Some appear to have been involved in the failure, which was a brittle fracture failure.

The cement sample containing organic/inorganic resin, C2A-6, is shown in Figures 15 through 17. In Figure 15, the sample is shown before compressive strength testing. Figures 16 and 17 were taken at about 90 degrees from each other after being tested. A large piece of the sample has flaked, and there is some small flaking adjacent to it as seen in Figure 16. Several small air bubbles can be seen on the sample surface along with a large bubble that appears to have been involved in propagation of a crack (Figure 17); a horizontal fracture passes through that feature. This sample exhibited brittle fracture failure.

The VES sample containing all organic resin, D1A-1, is shown in Figures 18 through 20. In Figure 18, the sample is shown before being tested. Note the rough finish with exposed resin beads that covers a majority of the sample surface. Figures 19 and 20 show the sample after being tested and were taken about 90 degrees from each other. The sample had a distinct bulge at the midpoint. Several small failure cracks barely are visible in both figures. The surface with exposed resin beads has become rough with protruding beads. Note the difference in sample height before and after being tested. This sample exhibited a ductile compressive failure.

The VES sample containing organic/inorganic resin, D2-35, is shown in Figures 21 through 23.
In Figure 21, the sample is shown before being tested. Note the smooth surface finish over all. Figures 22 and 23 show the sample after compressive strength testing and were taken at about 90 degrees from each other. The sample had a distinct bulge at the midpoint. A large slab has split off, and several large cracks can be seen. Also, a number of fine cracks are detectable in Figure 22. Some protruding resin beads can be seen on the surface. Note the difference in the sample height before and after being tested. This sample exhibited primarily ductile compressive failure.

These waste form samples have been stored in shielded drums throughout the project. Dose measurements indicate that the samples have experienced a total beta/gamma dose of $0.43 \times 10^{6}$ to $2.21 \times 10^{6} \mathrm{rad}$ during storage. That dose caused severe degradation of the polyethylene sample containers, which were discolored, embrittled, and cracked.

Eleven-Year-Old Waste Form Samples. On September 29, 1994, four 11-year-old waste form samples were compressive-tested per ASTM C3913 using the same Tinuis Olsen testing machine, which was calibrated on September 28 , 1994. The samples were tested dry using sulfur leveling caps applied per ASTM C617. ${ }^{14}$ One sample of each type of ion-exchange resin waste type (all organic and organic/inorganic) in each solidification agent (portland cement and VES) were tested. The initial test results were presented in Reference 12.

The samples after compressive strength testing are shown in Figures 24 through 27 . The concrete samples failed in a brittle manner with a vertical cracking pattern and some flaking. One VES sample, D1A-29, bulged in the center of the cylinder as had all previous VES samples. Vertical cracking took place within the bulging center area. That VES sample failure appeared to be ductile. Examination of the second VES sample, D2-34, indicates that it failed in brittle fracture, with a large, near-vertical crack and little or no bulging of the center section. Similar brittle failures were experienced with the externally irradiated VES waste form samples tested earlier in this program (Reference 7). 


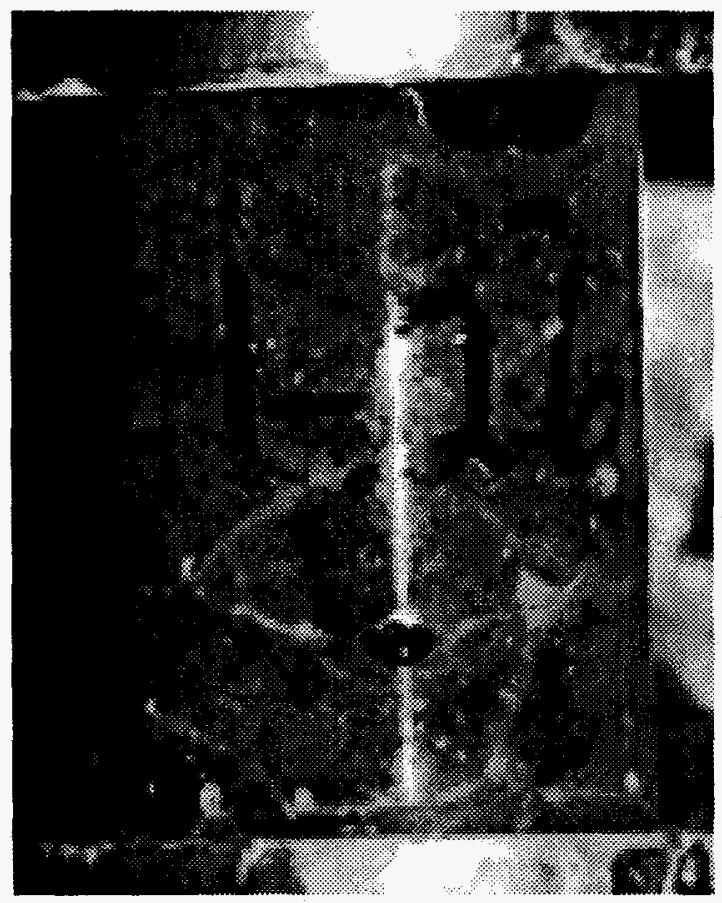

Figure 12. Eight-year-old sample C1-26 organic ion-exchange resin in portland cement before being tested.

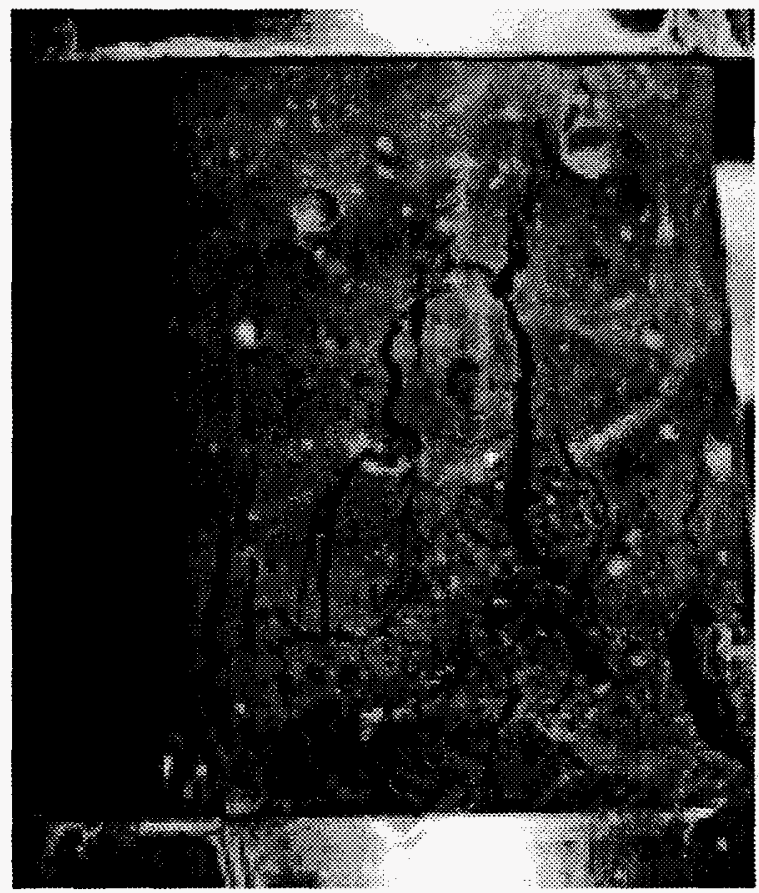

Figure 13. Eight-year-old sample $\mathrm{Cl}-26$ organic ion-exchange resin in portland cement after being tested (front view).

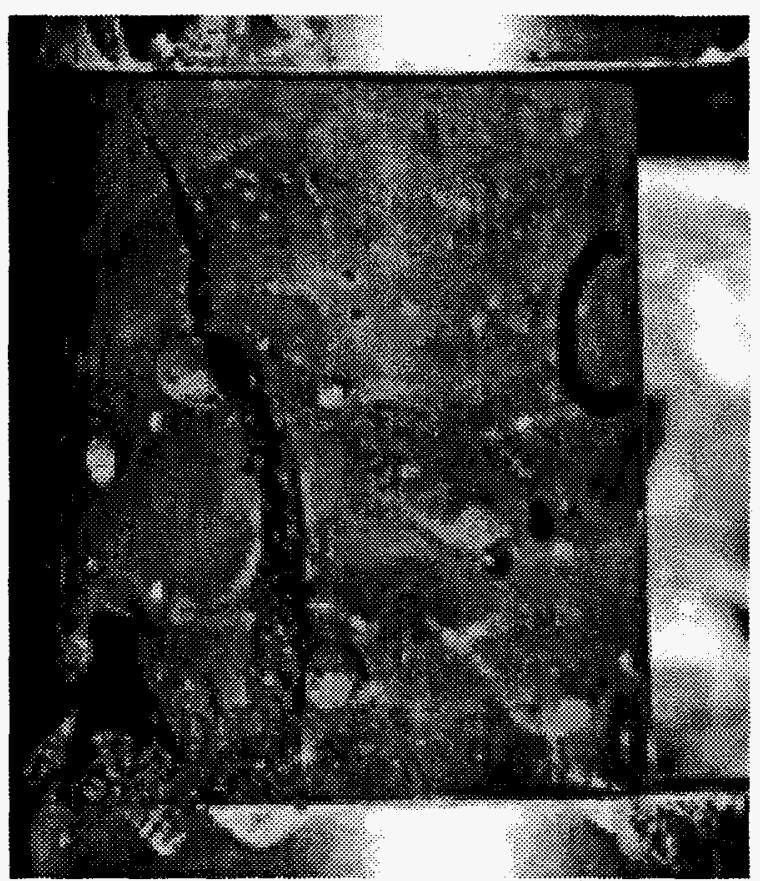

Figure 14. Eight-year-old sample C1-26 organic ion-exchange resin in portland cement after being tested (side view).

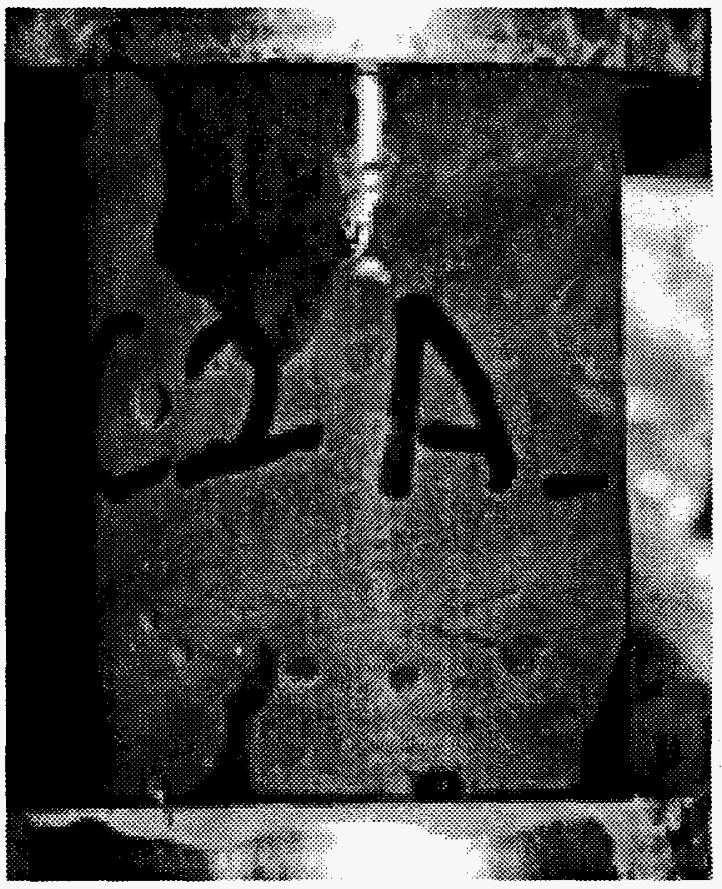

Figure 15. Eight-year-old sample C2A-6 organic/inorganic ion-exchange resin in portland cement before being tested. 


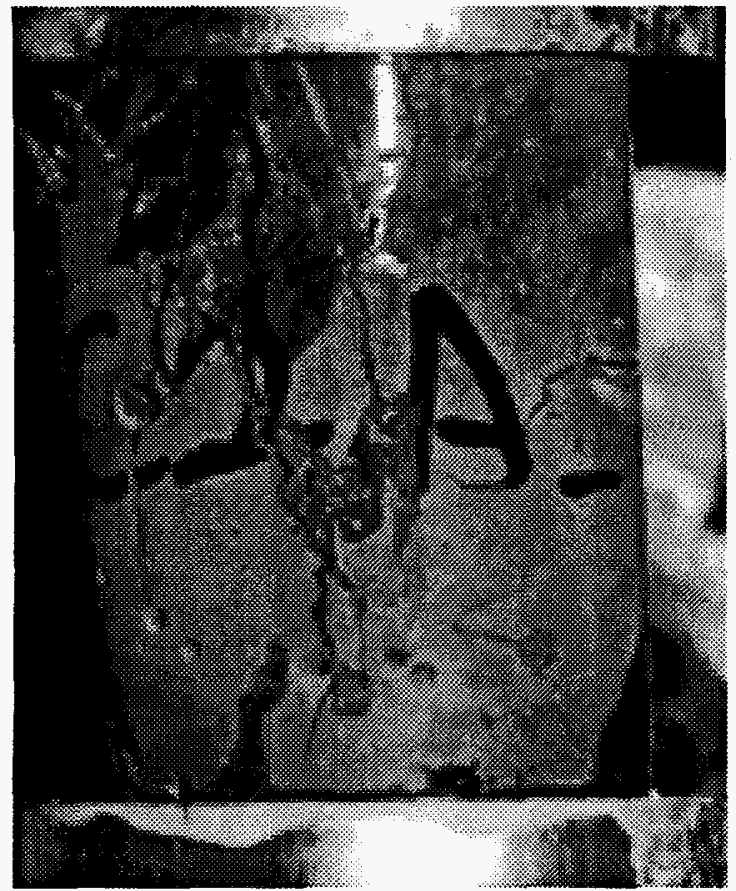

Figure 16. Eight-year-old sample C2A-6 organic/inorganic ion-exchange resin in portland cement after being tested (front view).

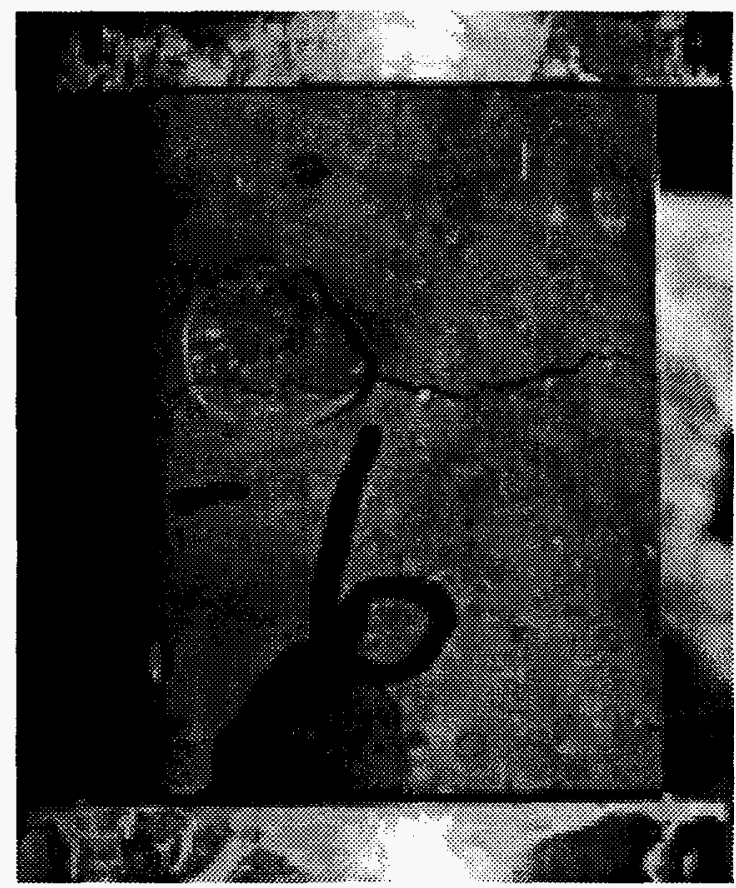

Figure 17. Eight-year-old sample C2A-6 organic/inorganic ion-exchange resin in portland cement after being tested (side view).

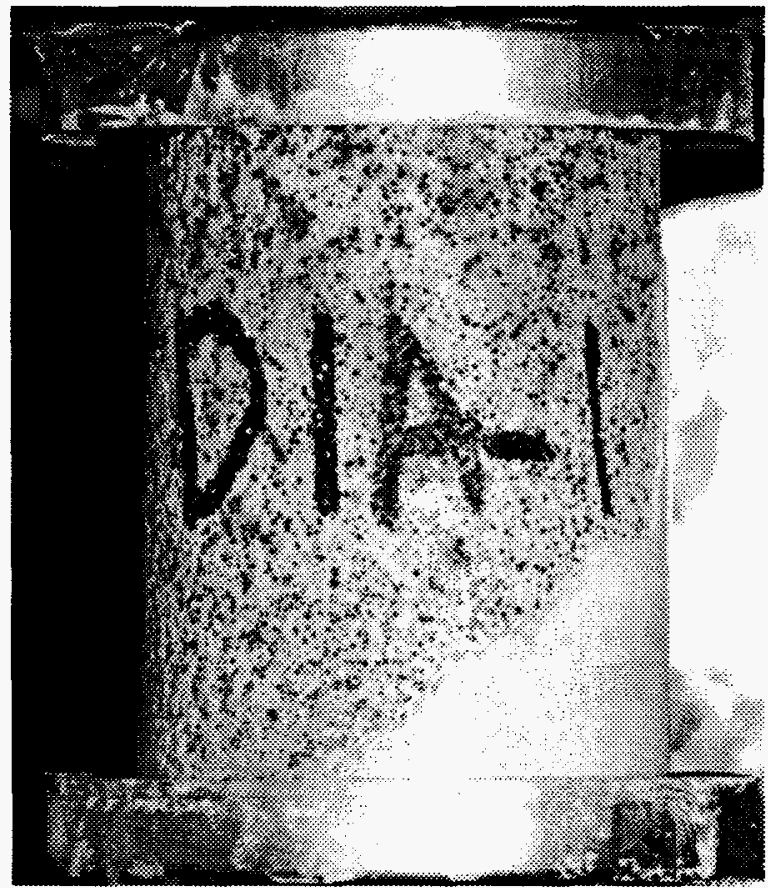

Figure 18. Eight-year-old sample DIA-1 organic ion-exchange resin in vinyl ester-styrene before being tested.

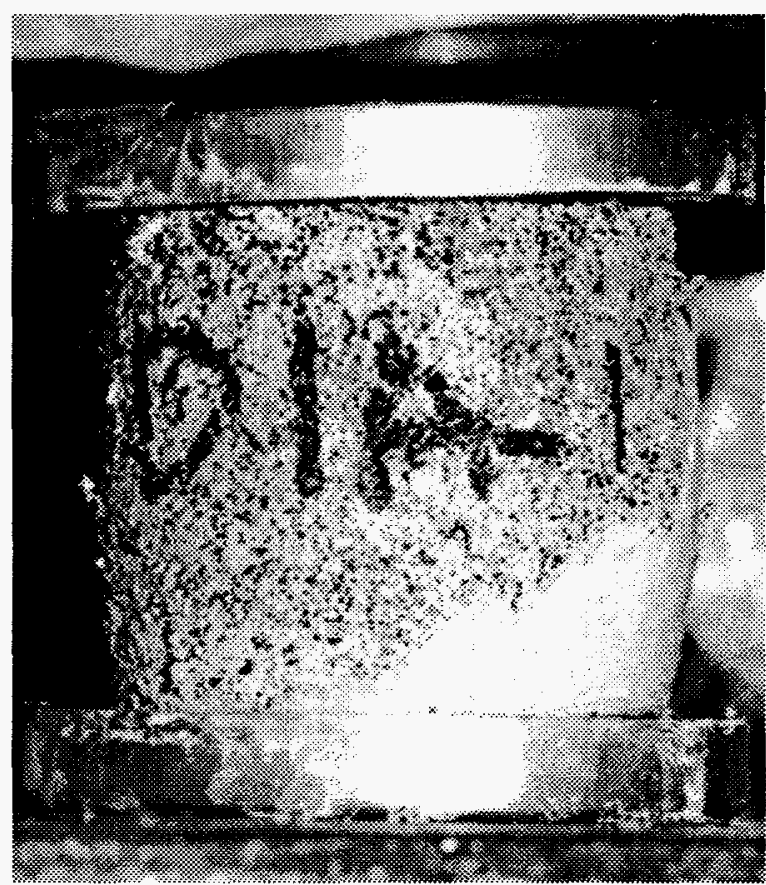

Figure 19. Eight-year-old sample D1A-1 organic ion-exchange resin in vinyl ester-styrene after being tested (front view). 


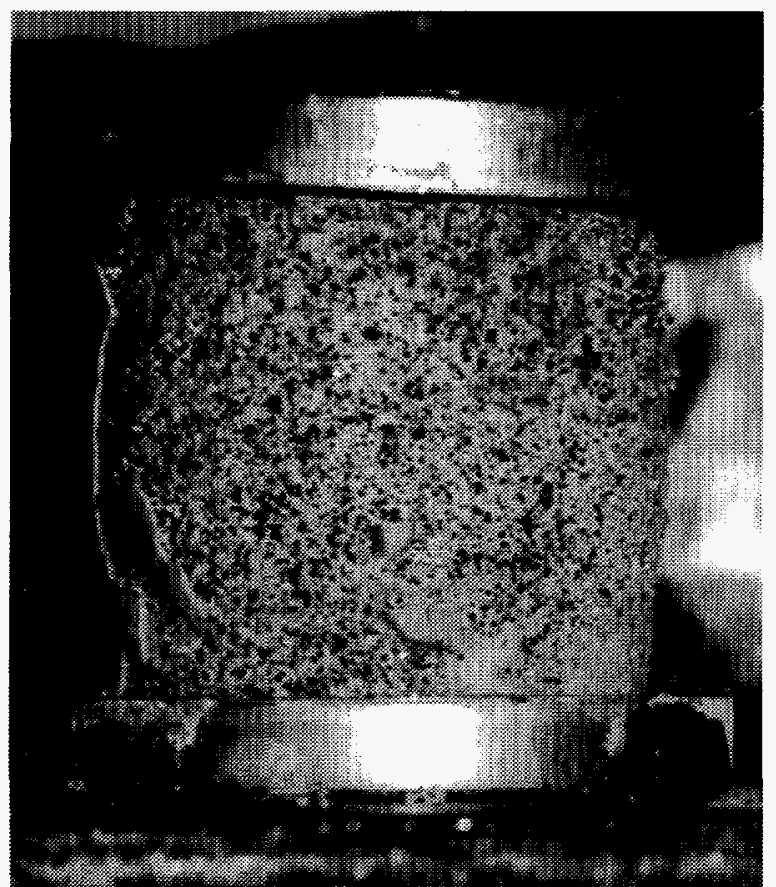

Figure 20. Eight-year-old sample D1A-1 organic ion-exchange resin in vinyl ester-styrene after being tested (side view).

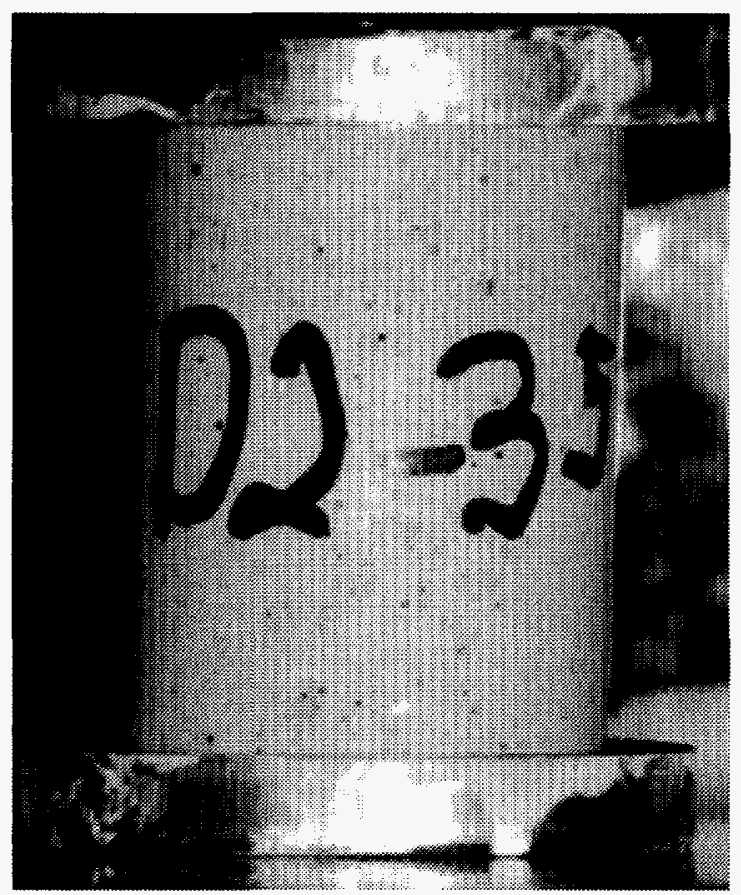

Figure 21. Eight-year-old sample D2-35 organic/inorganic ion-exchange resin in vinyl ester-styrene before being tested.

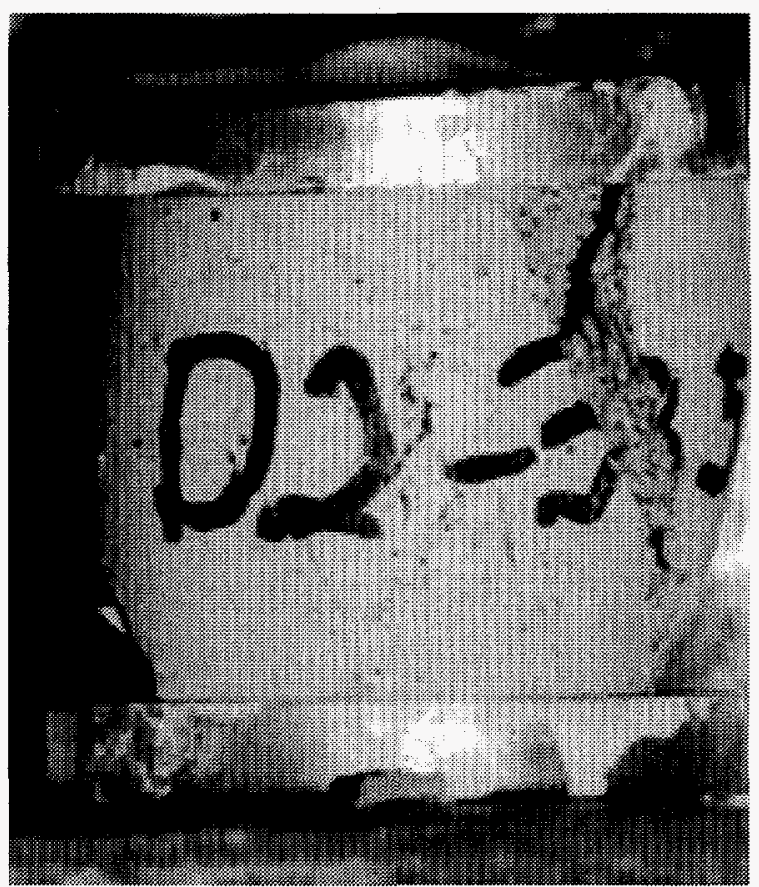

Figure 22. Eight-year-old sample D2-35 organic/inorganic ion-exchange resin in vinyl ester-styrene after being tested (front view).

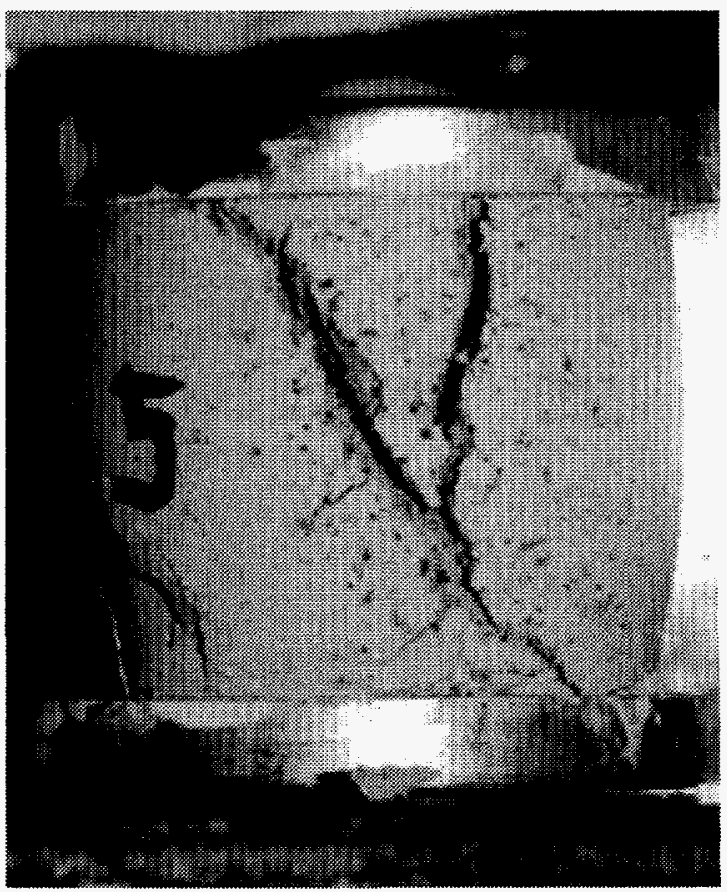

Figure 23. Eight-year-old sample D2-35 organic/inorganic ion-exchange resin in vinyl ester-styrene after being tested (side view). 


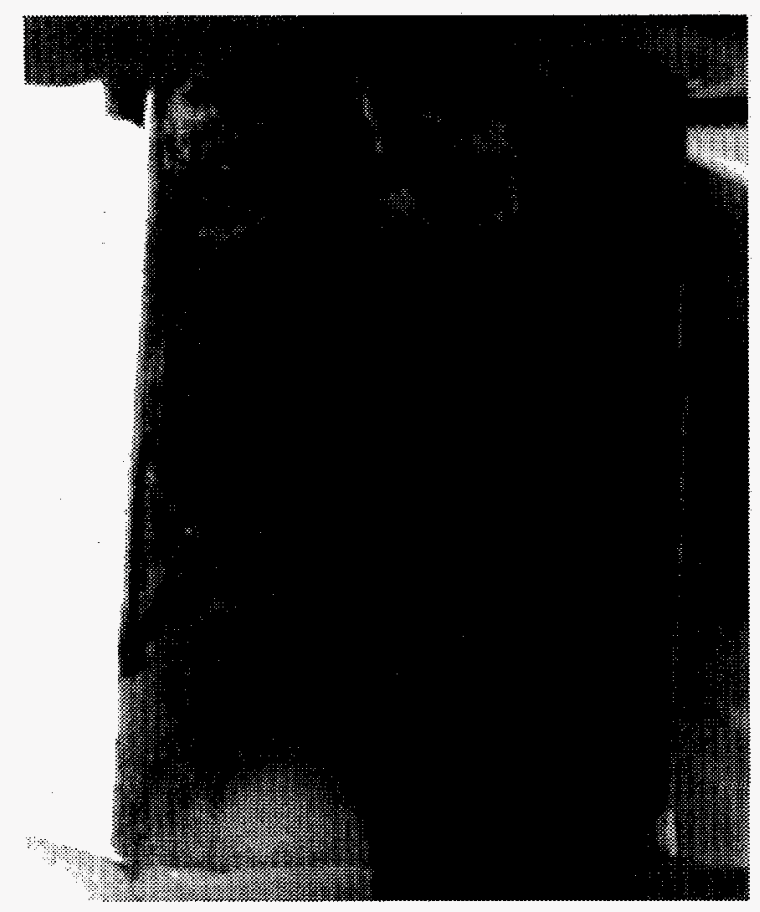

Figure 24. Eleven-year-old sample C1-24 organic ion-exchange resin in portland cement after being tested.

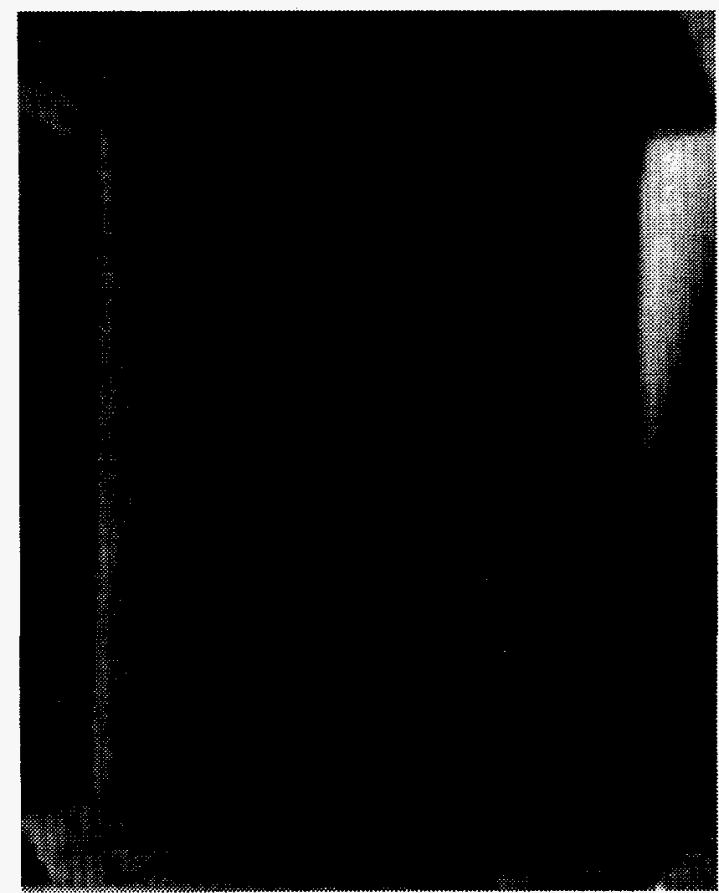

Figure 25. Eleven-year-old sample C2A-14 organic/inorganic ion-exchange resin in portland cement after being tested.

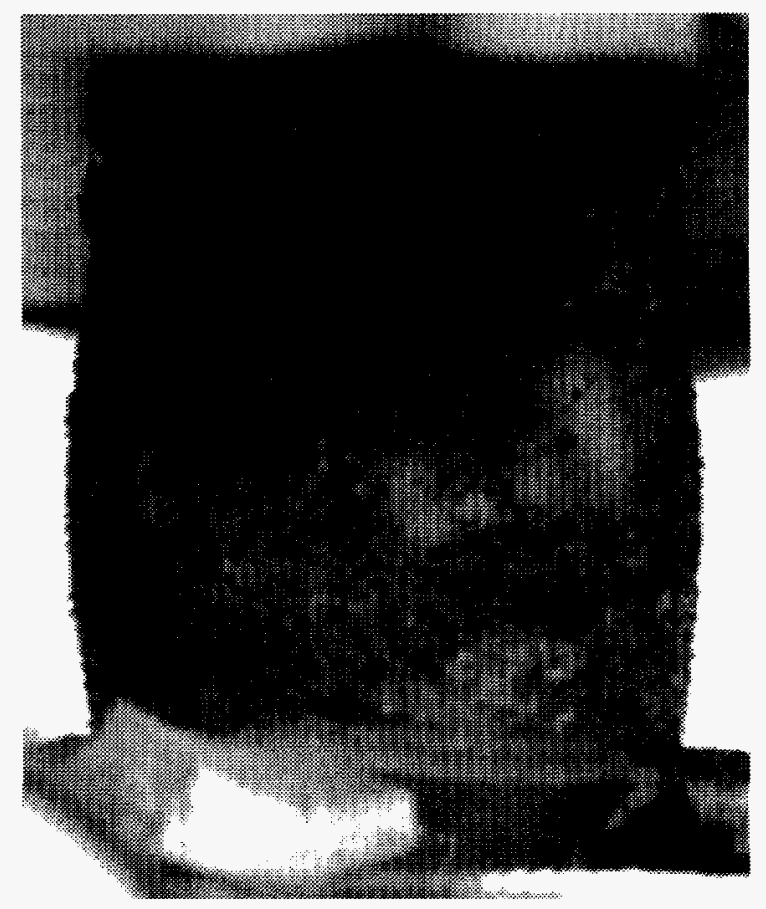

Figure 26. Eleven-year-old sample D1A-29 organic ion-exchange resin in vinyl ester-styrene after being tested.

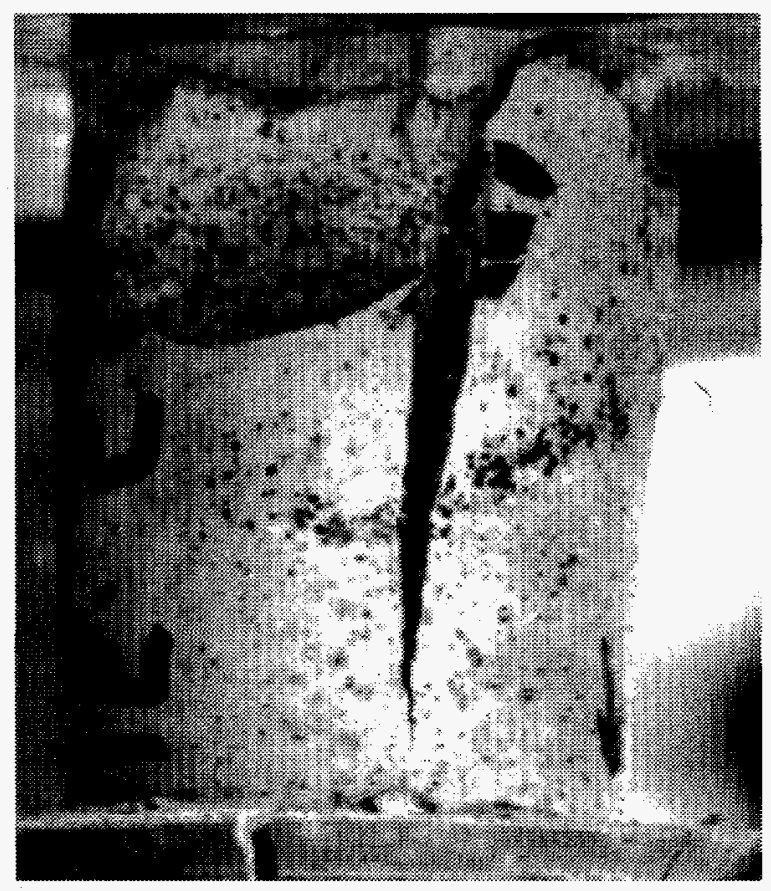

Figure 27. Eleven-year-old sample D2-34 organic/inorganic ion-exchange resin in vinyl ester-styrene after being tested. 
The cement sample containing all organic resin, $\mathrm{C} 1-24$, is shown in Figure 24 after being tested. This sample exhibits longitudinal cracking with a large flake still in place. Also visible are several small casting air bubbles. Larger bubbles had been noted on the opposite side from this view. This sample exhibited typical brittle fracture failure.

The cement sample containing organic/inorganic resin, C2A-14, is shown in Figure 25 after being tested. Near maximum load, a section broke off and a crack propagated up the sample axis. Also visible is a large air bubble. Lack of photo quality limits further definition. The sample exhibited typical brittle fracture failure.

The VES sample containing all organic resin, D1A-29, is shown in Figure 26 after being tested. This sample developed a distinct bulge at the midpoint as had all previous VES samples. A large failure crack developed, visible as a diagonal line at midpoint. The surface has become rough with protruding resin beads (seen clearly on the left edge of the sample). This sample exhibited a ductile compressive failure.

The VES sample containing organic/inorganic resin, D2-34, is shown in Figure 27 after being tested. A corner slab broke off at about $90 \%$ of maximum load, and a large longitudinal crack propagated from that area as loading continued. The sample exhibited little or no bulging in the center section. All unbroken surfaces are as-cast smooth. This sample exhibited a brittle fracture failure. Similar brittle failures were experienced with the irradiated VES waste form samples tested earlier in this program (Reference 7).

These waste form samples have been stored in shielded drums throughout the project. Dose measurements indicate that the samples have experienced a total beta/gamma dose of $0.54 \times 10^{6}$ to $2.92 \times 10^{6} \mathrm{rad}$. That dose has caused serious degradation of the polyethylene sample containers, which were discolored, embrittled, and cracked. In order to preserve sample identity, a number of containers of remaining samples were replaced with cardboard tubes during the 1991 test operation.

Twelve-Year-OId Waste Form Samples. On August 9, 1995, eight 12-year old waste form samples were compressive-tested per ASTM C39 ${ }^{13}$ using the same Tinuis Olsen testing machine, which was calibrated on July 18, 1995. The samples were tested dry using sulfur leveling caps applied per ASTM C617.14 Normally, one sample of each type of ion-exchange resin waste type (all organic and organic/inorganic) in each solidification agent (portland cement and VES) was tested. In 1995, two samples of each type were tested.

The samples tested are shown in Figures 28 through 51 . The concrete samples broke in a nearvertical cracking pattern with flaking. The VES samples containing organic resin bulged in the center of the cylinder as had most previous VES samples. Vertical cracking took place within the bulging center area. Failure of these VES samples appeared to be ductile. Examination of the VES samples containing organic/inorganic resin indicates that failures were more like brittle fractures. These samples had higher self-irradiation doses than the VES waste form samples containing organic resin because of higher radionuclide content of the resin wastes (Reference 7). Large vertical cracks are evident in these samples. Similar failures were experienced with the externally irradiated VES waste form samples tested earlier in this program (Reference 7 ).

The cement samples containing all organic resin, C1-31 and C1-35, are shown in Figures 28 through 33 . The samples before being tested are pictured in Figures 28 and 31 . Figures 29 and 30 show sample C1-31 after being tested and were taken about 90 degrees from each other. Figures 32 and 33 show sample C1-35 after being tested and were also taken about 90 degrees from each other. These samples exhibit longitudinal cracking with heavy flaking, and dropped slabs of material during compressive loading, typical of brittle fracture. Both samples appear to be fully penetrated by cracks, with C1-35 almost totally flaked. Several small- to medium-sized casting air bubbles are visible on the surfaces of both samples. 


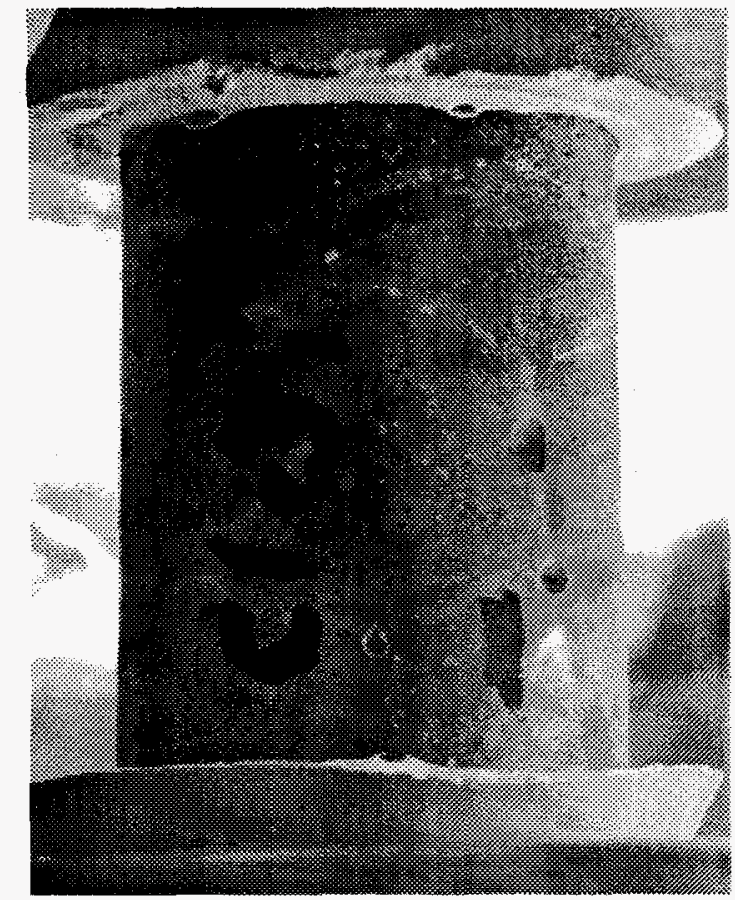

Figure 28. Twelve-year-old sample $\mathrm{Cl}-31$ organic ion-exchange resin in portland cement before being tested.

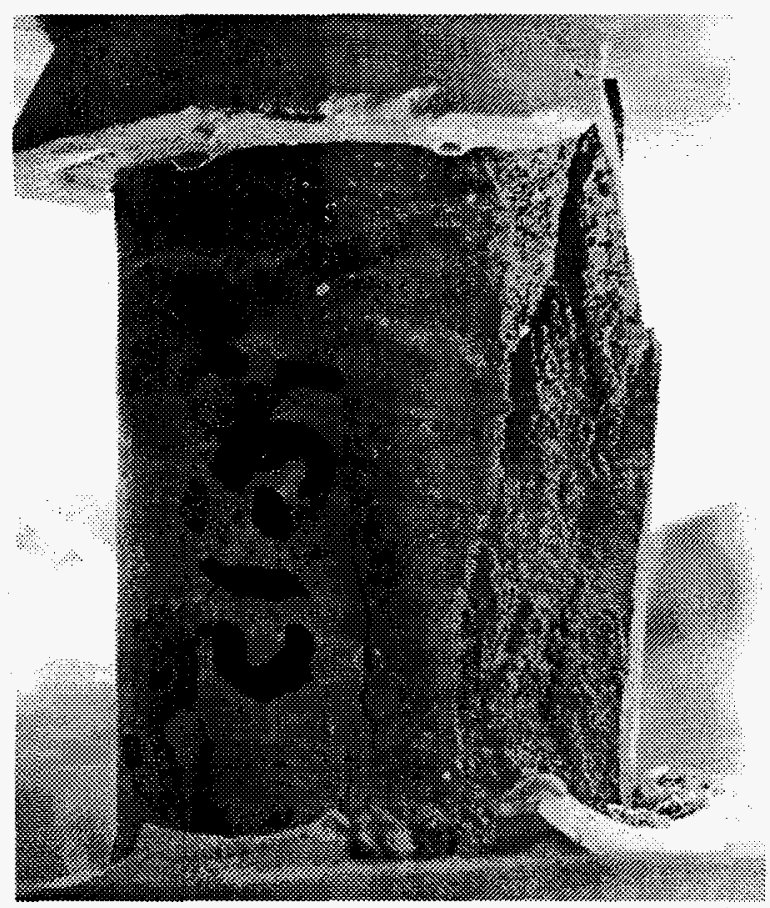

Figure 29. Twelve-year-old sample C $1-31$ organic ion-exchange resin in portland cement after being tested (front view).

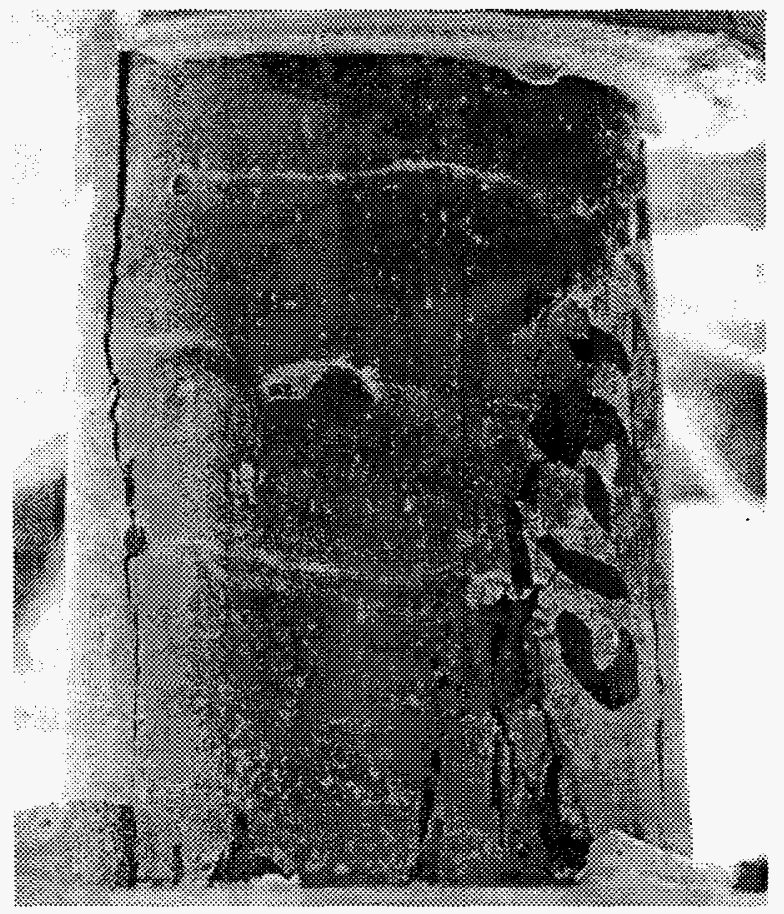

Figure 30. Twelve-year-old sample C1-31 organic ion-exchange resin in portland cement after being tested (side view).

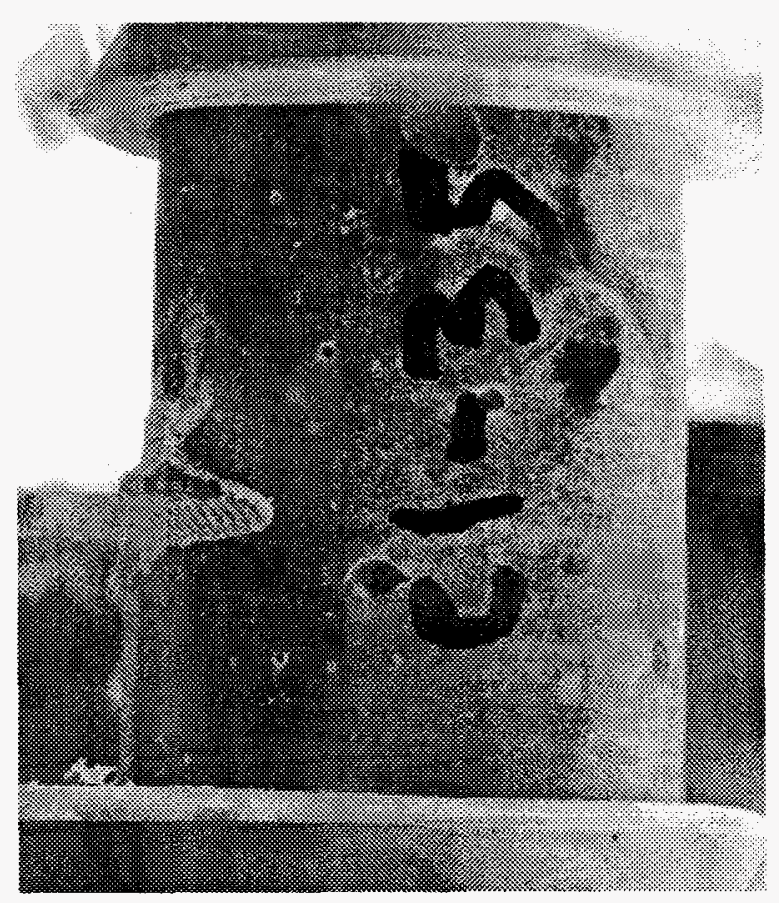

Figure 31. Twelve-year-old sample C1-35 organic ion-exchange resin in portland cement before being tested. 


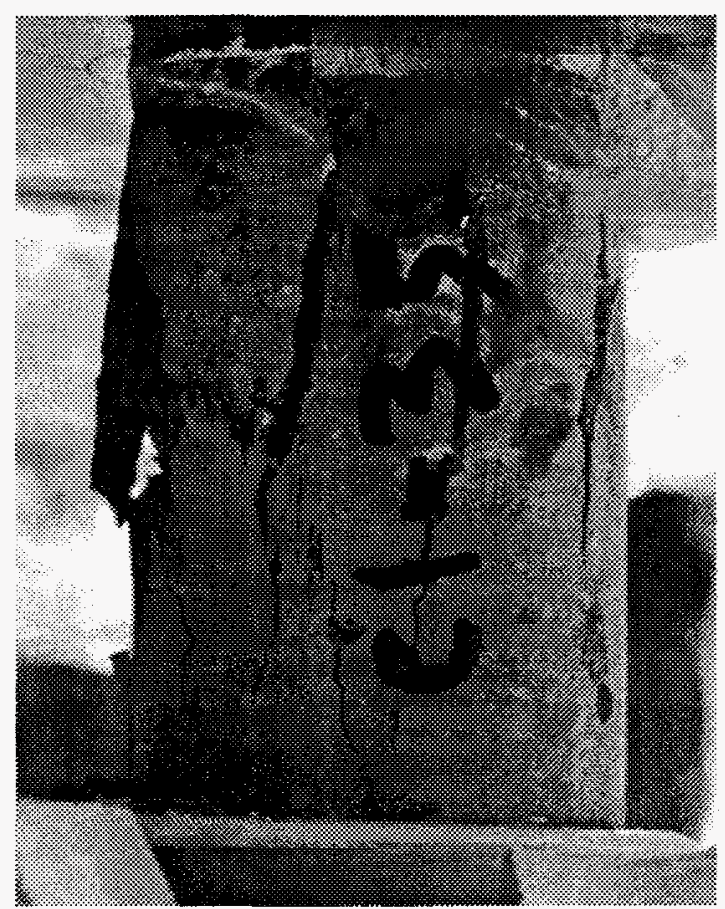

Figure 32. Twelve-year-old sample C1-35 organic ion-exchange resin in portland cement after being tested (front view).

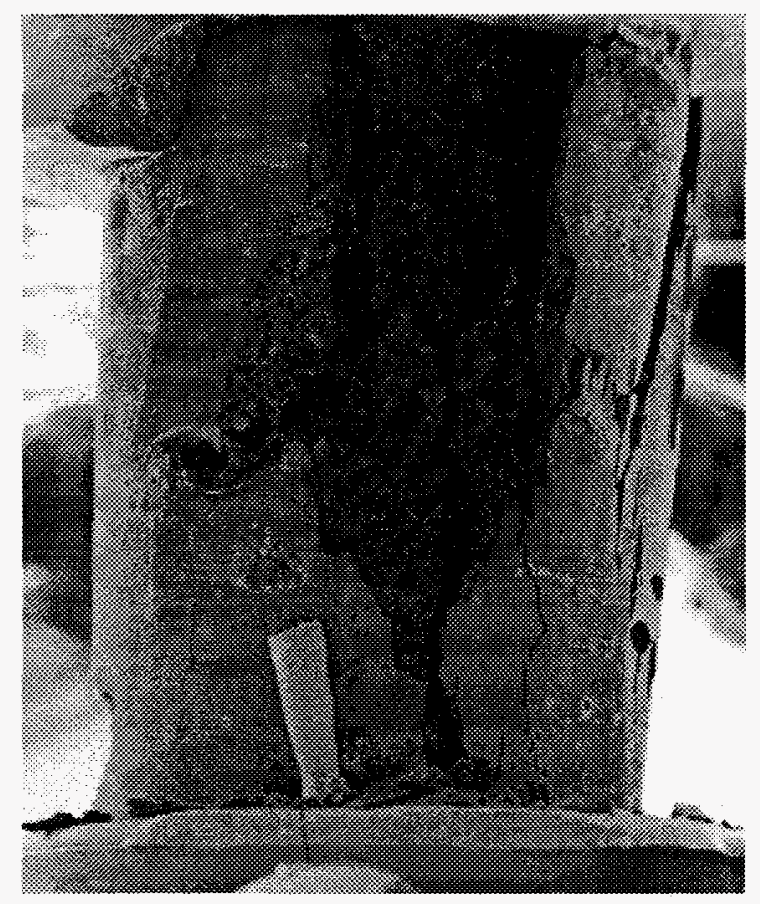

Figure 33. Twelve-year-old sample C1-35 organic ion-exchange resin in portland cement after being tested (side view).

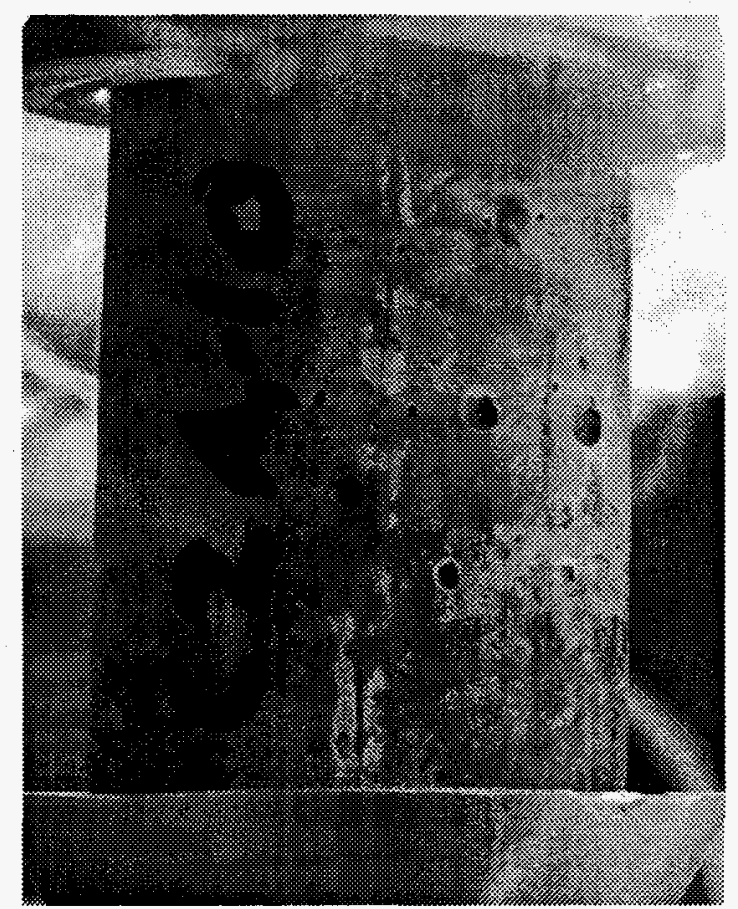

Figure 34. Twelve-year-old sample C2A-10 organic/inorganic ion-exchange resin in portland cement before being tested.

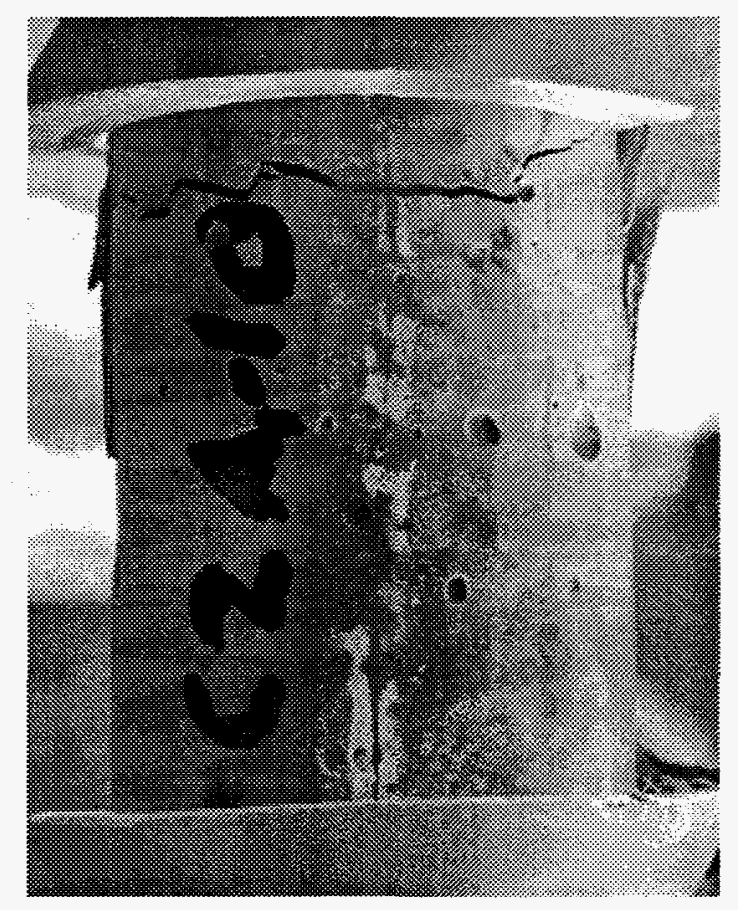

Figure 35. Twelve-year-old sample C2A-10 organic/inorganic ion-exchange resin in portland cement after being tested (front view). 


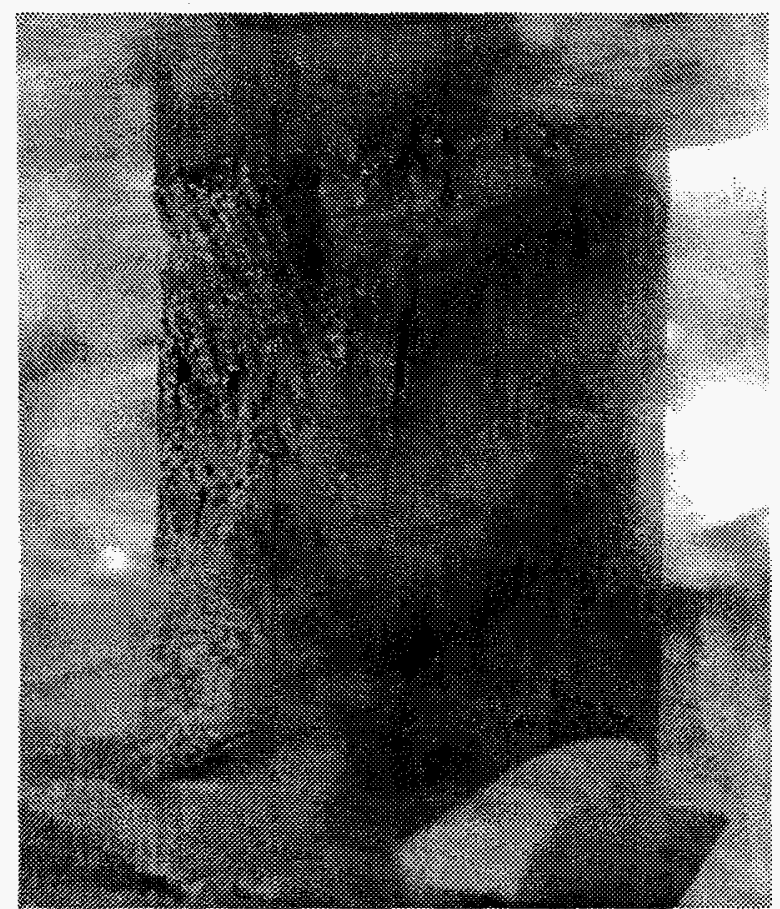

Figure 36. Twelve-year-old sample C2A-10 organic/inorganic ion-exchange resin in portland cement after being tested (side view).

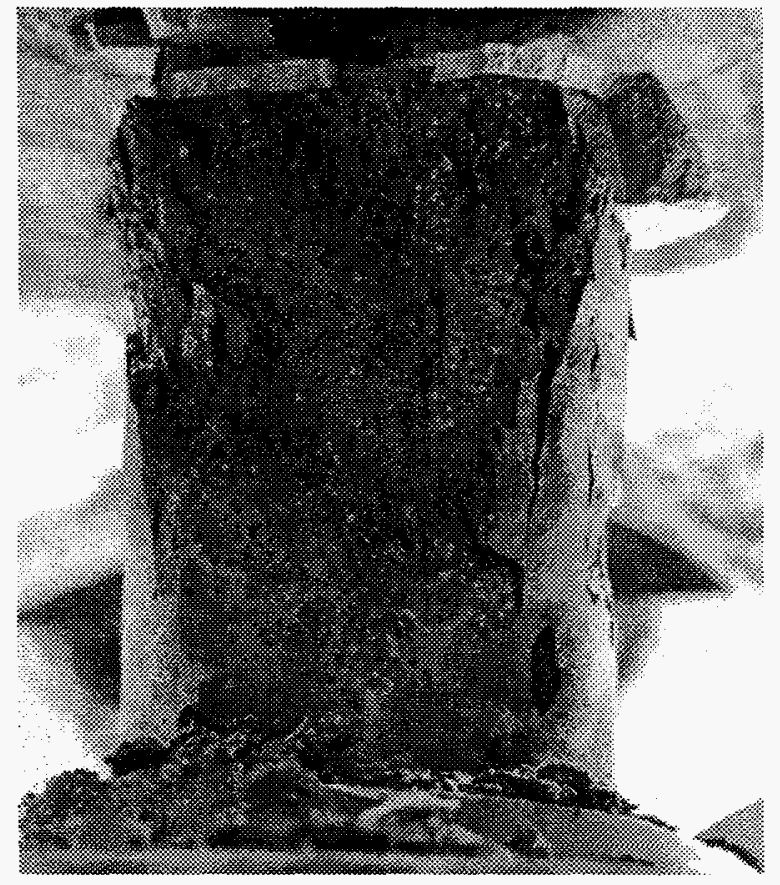

Figure 37. Twelve-year-old sample C2A-10 organic/inorganic ion-exchange resin in portland cement after being tested (back view).

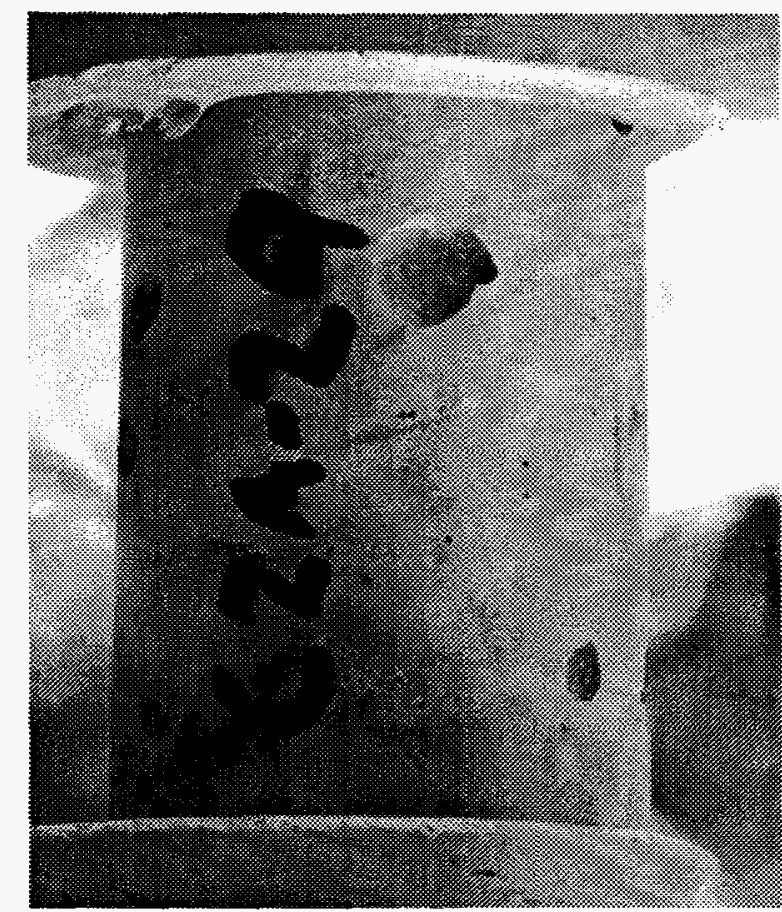

Figure 38. Twelve-year-old sample C2A-29 organic/inorganic ion-exchange resin in portland cement before being tested.

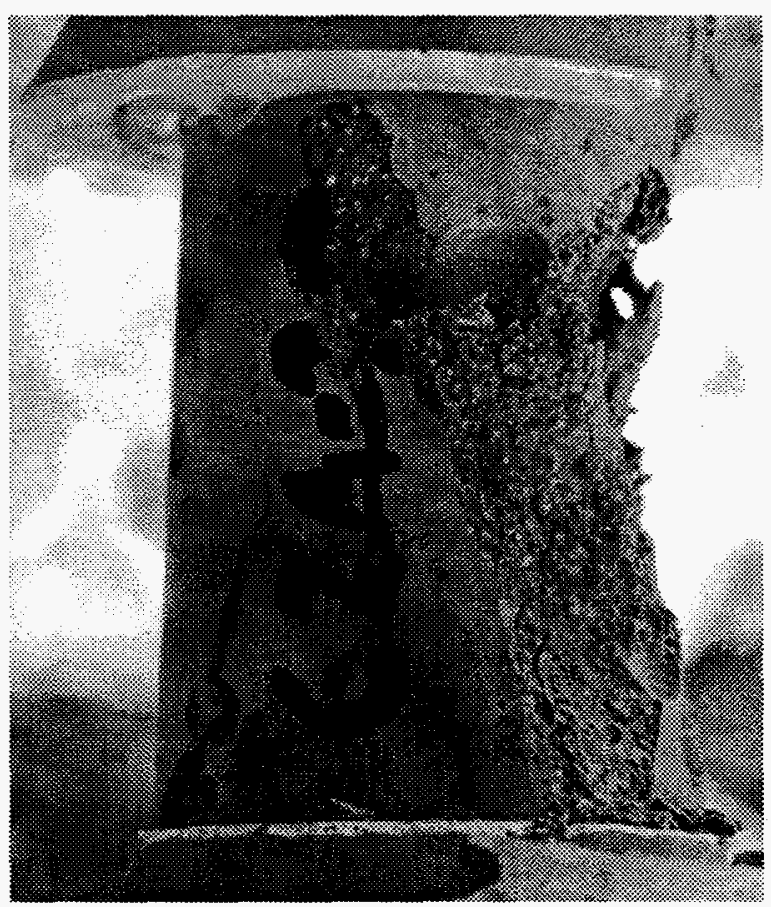

Figure 39. Twelve-year-old sample C2A-29 organic/inorganic ion-exchange resin in portland cement after being tested (front view). 


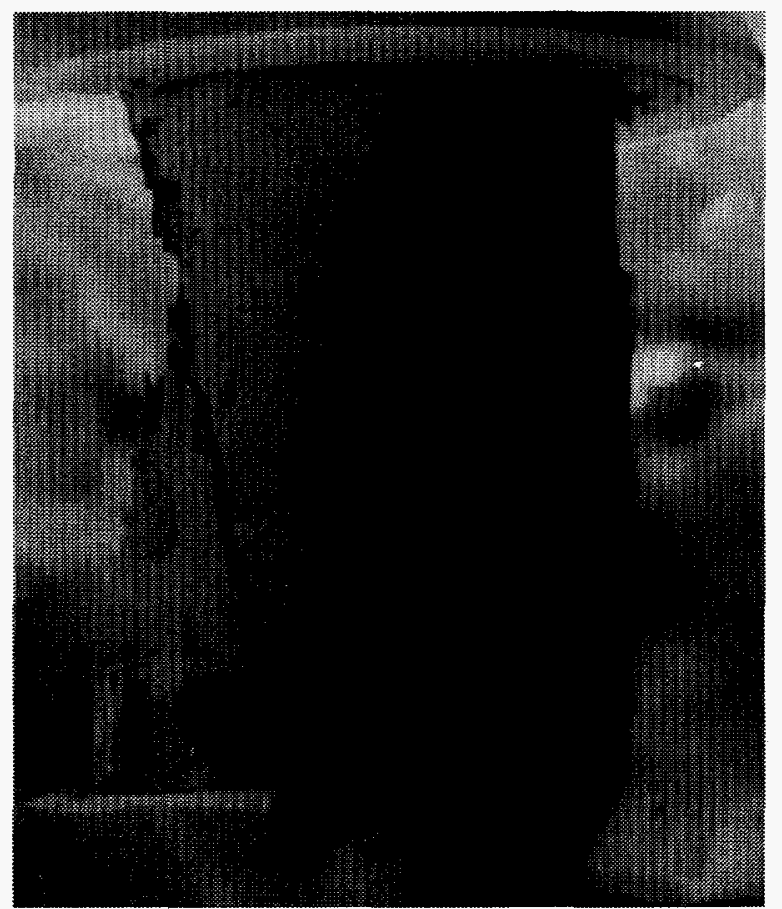

Figure 40. Twelve-year-old sample C2A-29 organic/inorganic ion-exchange resin in portland cement after being tested (side view).

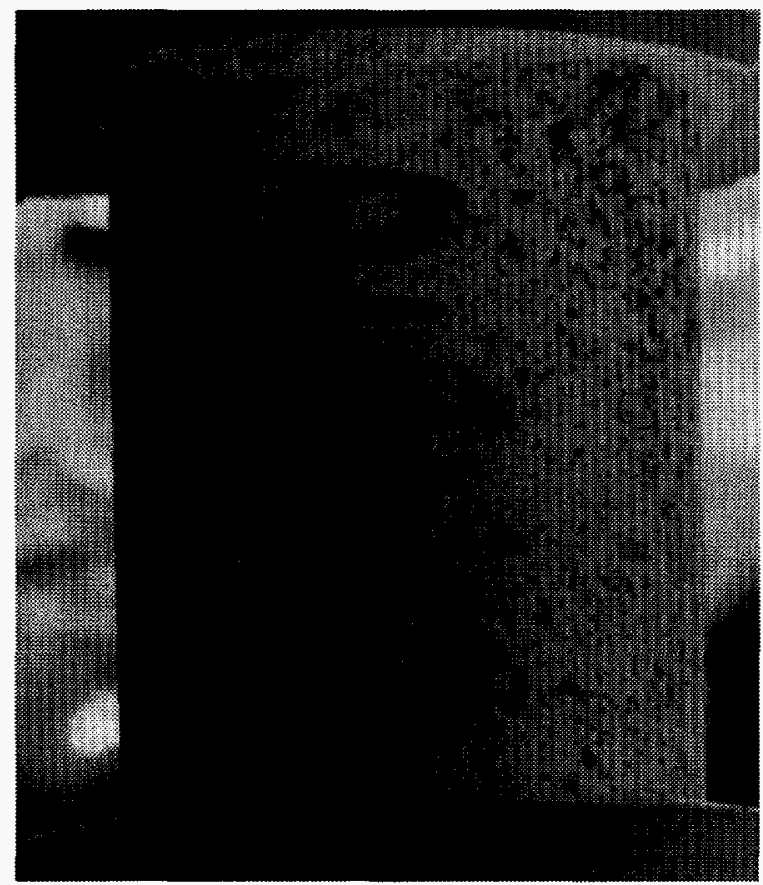

Figure 41. Twelve-year-old sample D1-13 organic ion-exchange resin in vinyl ester-styrene before being tested.

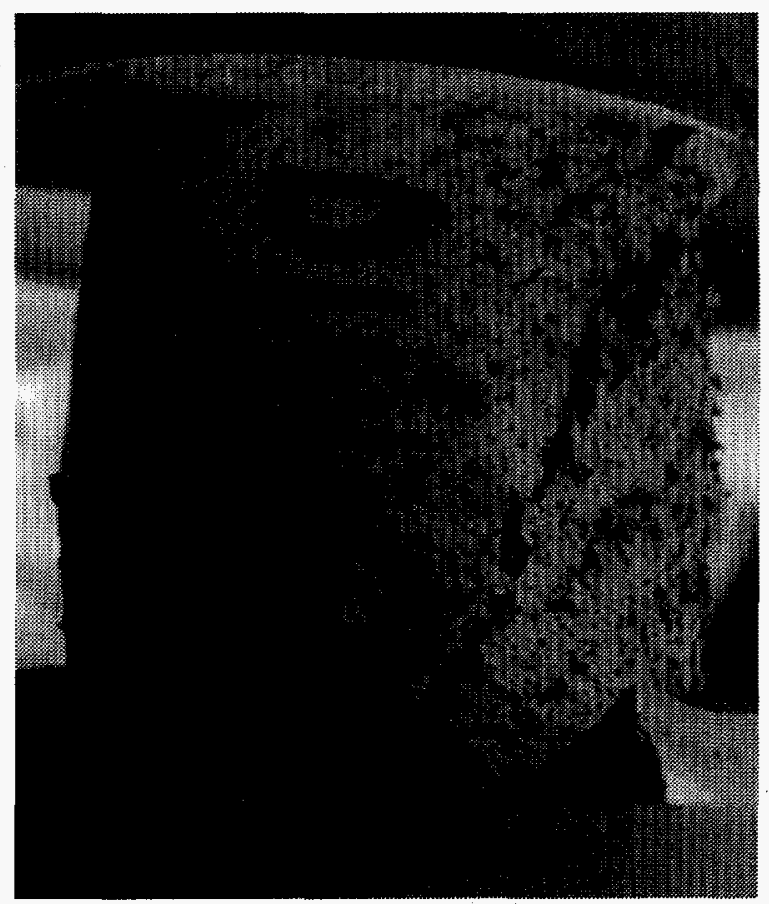

Figure 42. Twelve-year-old sample D1-13 organic ion-exchange resin in vinyl ester-styrene after being tested (front view).

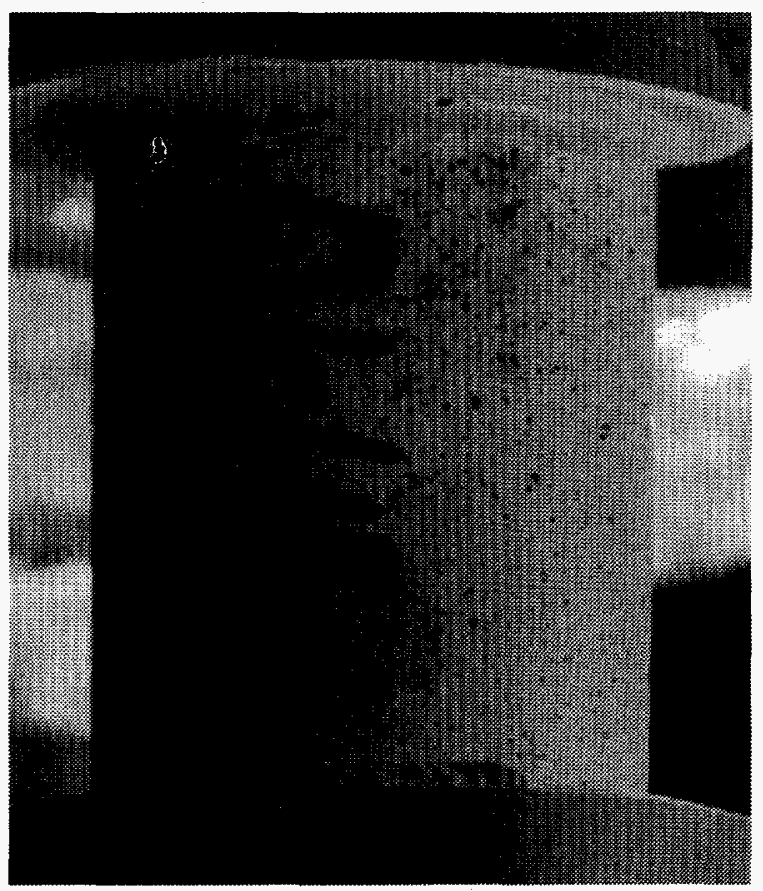

Figure 43. Twelve-year-old sample D1-14 organic ion-exchange resin in vinyl ester-styrene before being tested. 


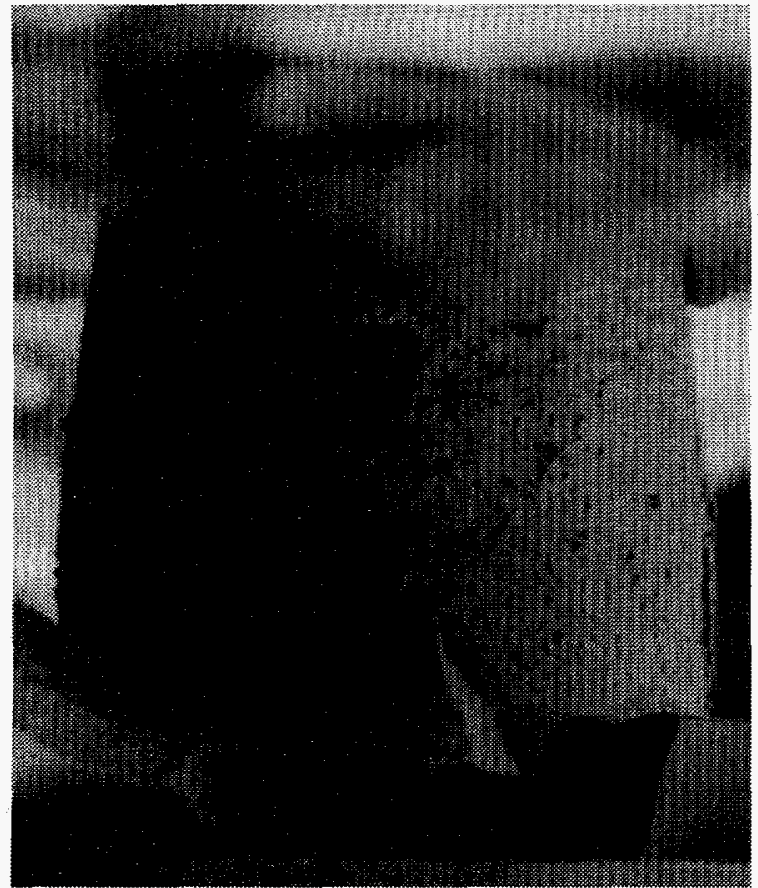

Figure 44. Twelve-year-old sample D1-14 organic ion-exchange resin in vinyl ester-styrene after being tested (front view).

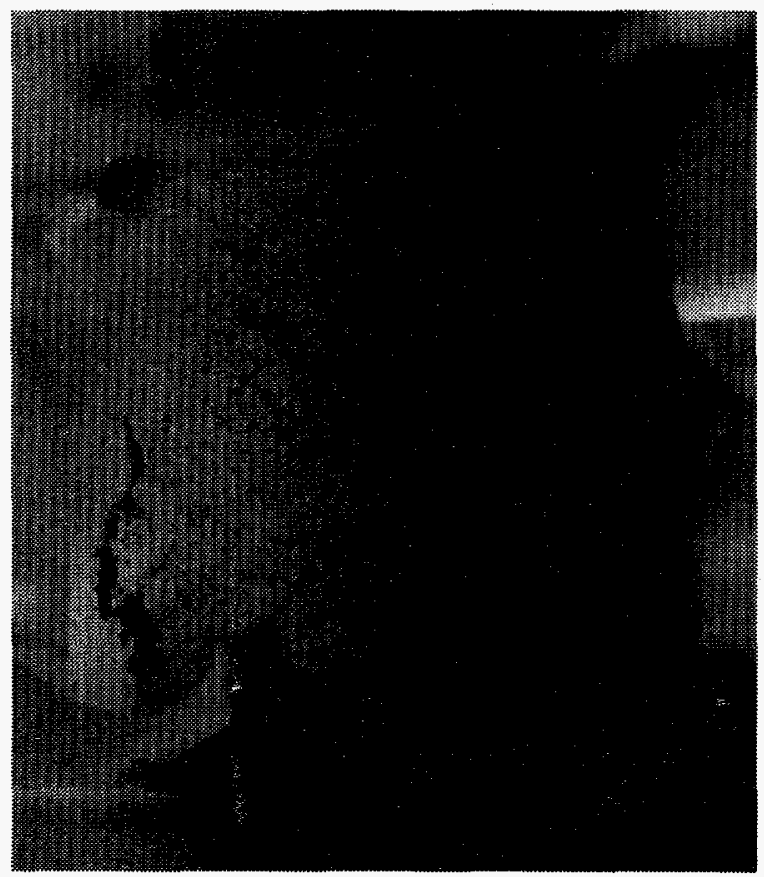

Figure 45. Twelve-year-old sample D1-14 organic ion-exchange resin in vinyl ester-styrene after being tested (side view).

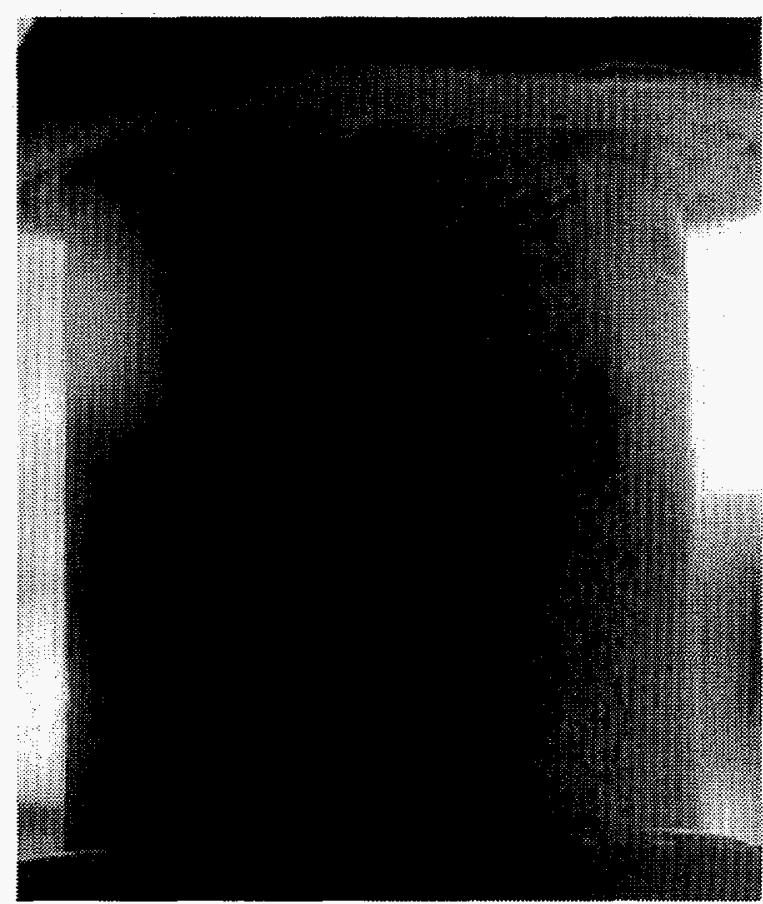

Figure 46. Twelve-year-old sample D2-1 organic/inorganic ion-exchange resin in vinyl ester-styrene before being tested.

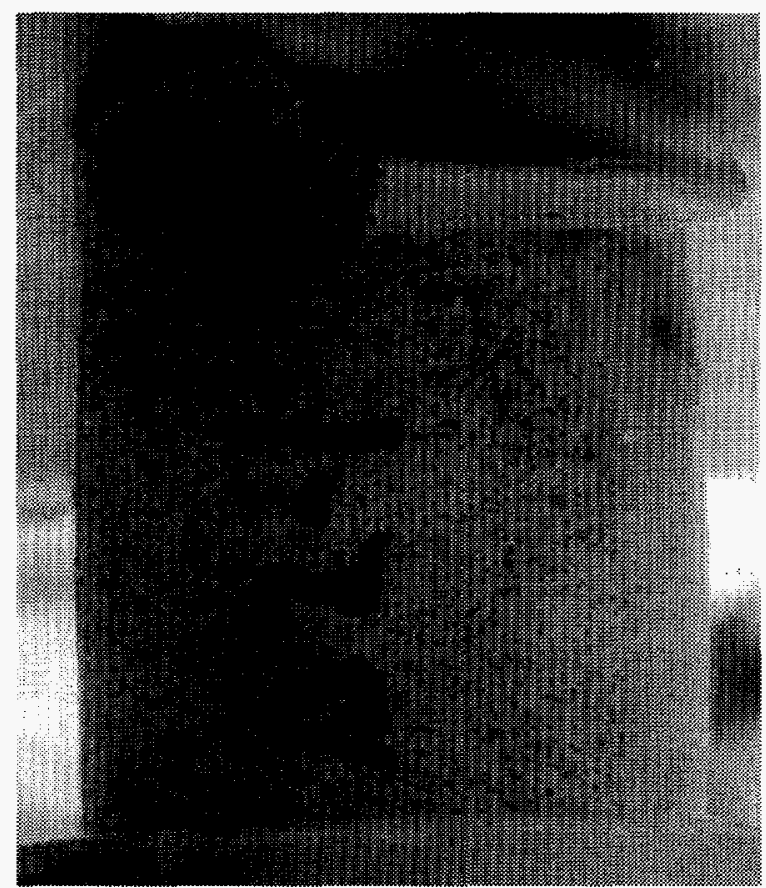

Figure 47. Twelve-year-old sample D2-1 organic/inorganic ion-exchange resin in vinyl ester-styrene after being tested (front view). 


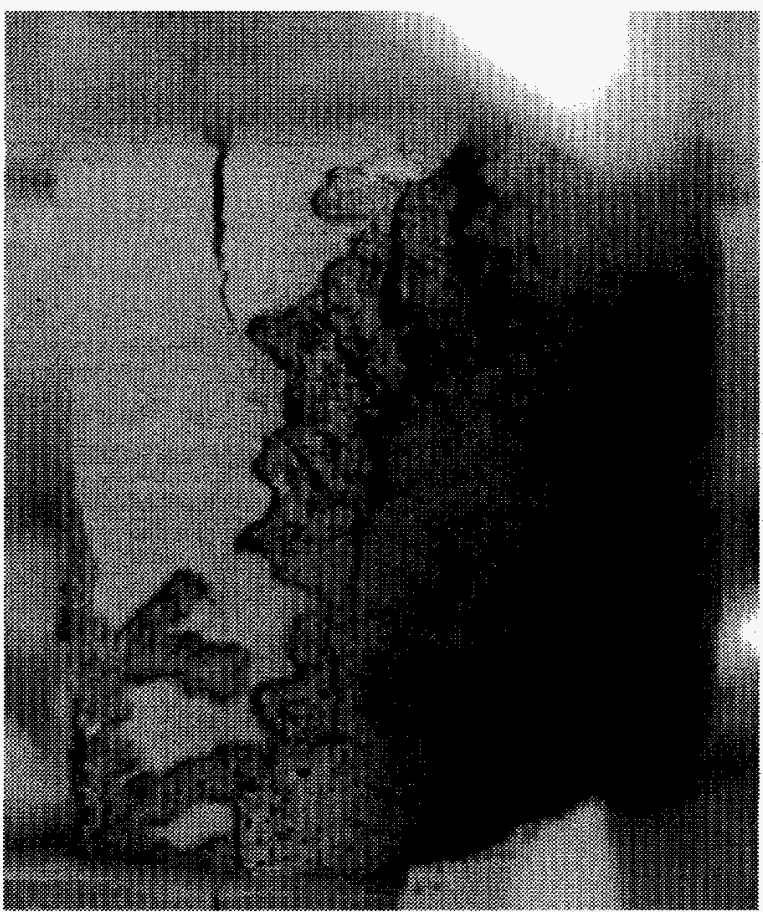

Figure 48. Twelve-year-old sample D2-1 organic/inorganic ion-exchange resin in vinyl ester-styrene after being tested (back view).

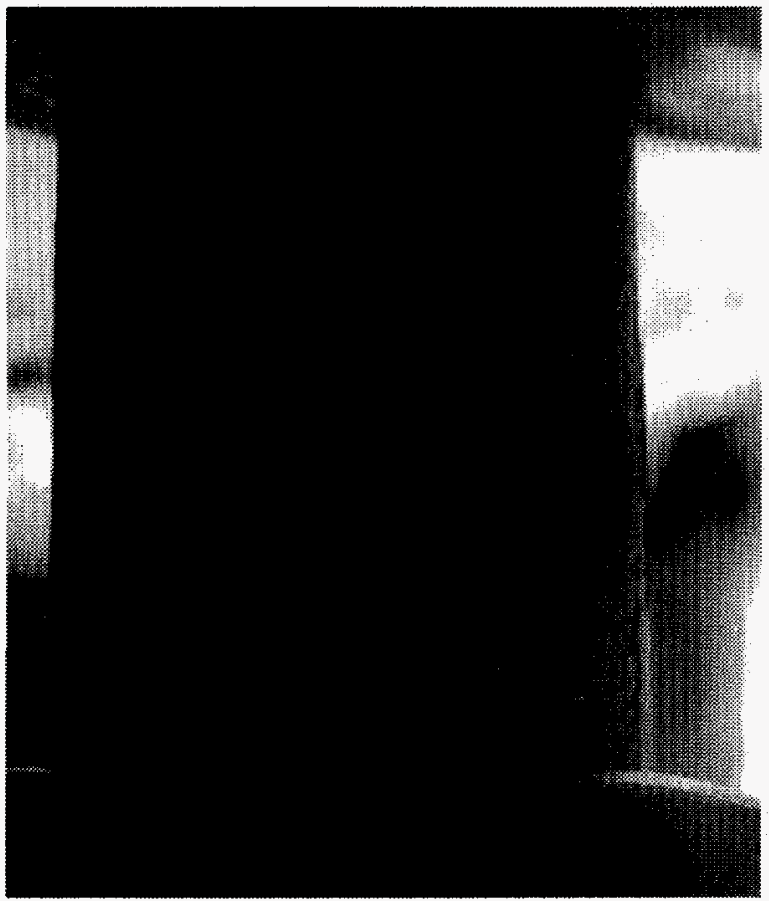

Figure 49. Twelve-year-old sample D2-12 organic/inorganic ion-exchange resin in vinyl ester-styrene before being tested.

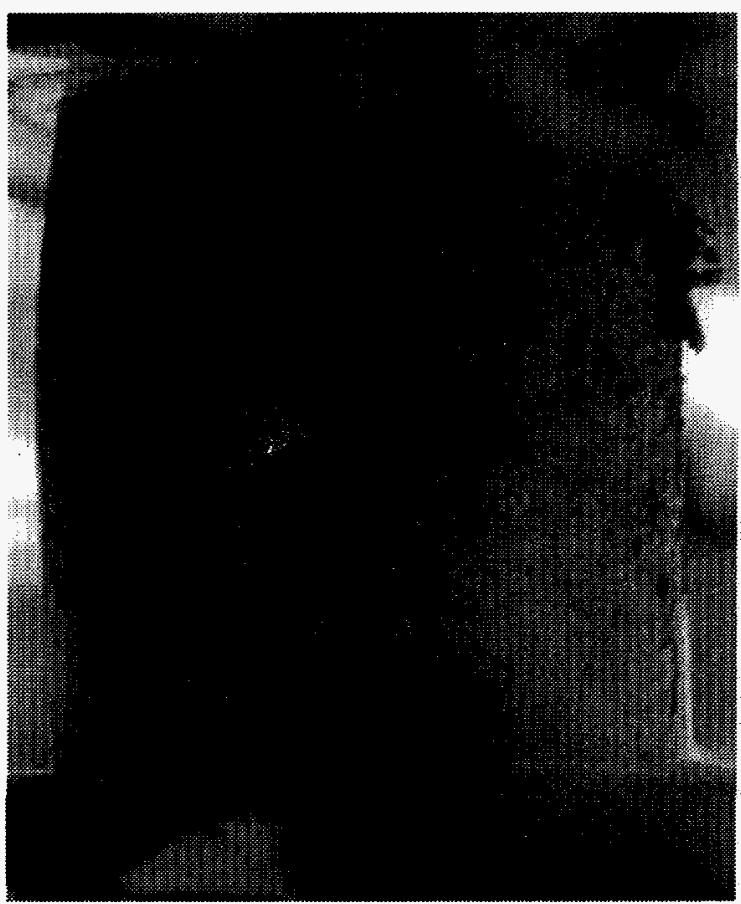

Figure 50. Twelve-year-old sample D2-12 organic/inorganic ion-exchange resin in vinyl ester-styrene after being tested (front view).

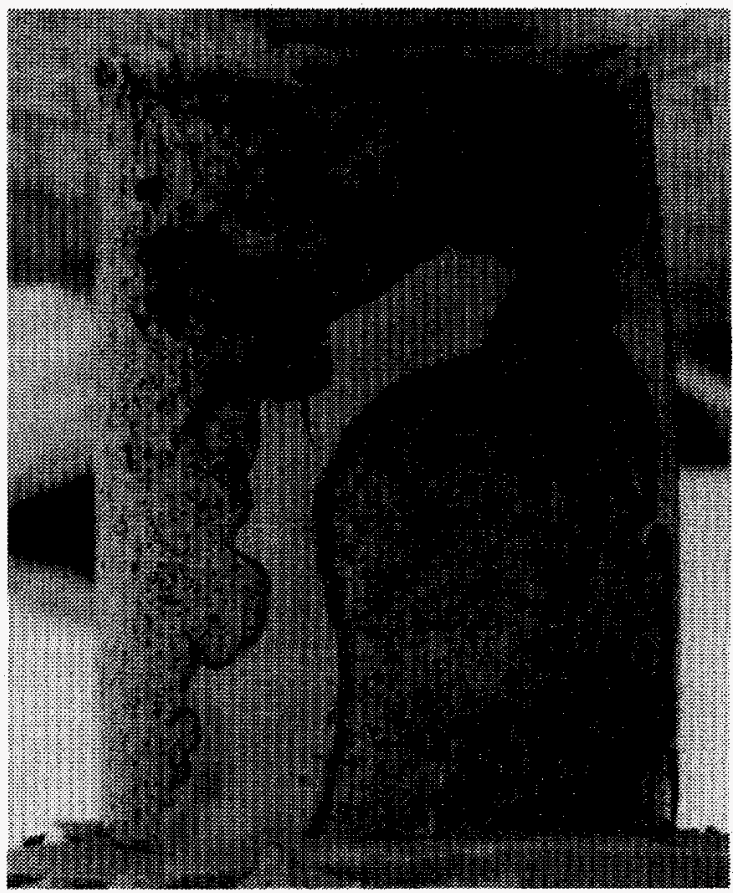

Figure 51. Twelve-year-old sample D2-12 organic/inorganic ion-exchange resin in vinyl ester-styrene after being tested (side view). 
The cement samples containing organic/inorganic resins, $\mathrm{C} 2 \mathrm{~A}-10$ and $\mathrm{C} 2 \mathrm{~A}-29$, are shown in Figures 34 through 40 . The samples before being tested are pictured in Figures 34 and 38. Figures 35,36 , and 37 show sample C2A-10 after being tested and were taken at about 90 degrees from each other. Figures 39 and 40 show sample C2A-29 after being tested and were also taken at about 90 degrees from each other. These samples exhibited longitudinal cracking with heavy flaking. Sample C2A-10 also has a horizontal crack at one end. These samples dropped slabs of material during loading. A number of air bubbles (both small and large) are visible on the surfaces of both samples. These samples exhibited typical brittle fracture failures.

The VES samples containing all organic resins, D1-13 and D1-14, are shown in Figures 41 through 45 . The samples before being tested are pictured in Figures 41 and 43. Figure 42 shows the front view of sample D1-13 after being tested. Figures 44 and 45 show sample D1-14 after being tested and were taken about 90 degrees from each other. Both samples developed a distinct bulge at midpoint during testing, as had most of the previously tested VES samples. Large diagonal failure cracks occurred in both samples, with many small surface cracks evident. The surfaces of both are rough and have protruding resin particles. These samples exhibited primarily ductile compressive failure.

The VES samples containing organic/inorganic resins, D2-1 and D2-12, are shown in Figures 46 through 51 . The samples before compressive strength testing are pictured in Figures 46 and 49. Figures 47 and 48 show sample D2-1 after being tested and were taken about 180 degrees from each other. Figures 50 and 51 show sample D2-12 after being tested and were taken about 90 degrees from each other. These samples bulged slightly at the midplane and shortened somewhat. Sample D2-1 suffered one large and one small vertical crack. The failure of sample D2-12 resulted in a shattering of one upper corner with many small cracks. The surfaces of both samples remained smooth, aside from cracks, with no protruding resins. Both samples had unusual sections of skin resulting from molding irregularities, which are seen on Figures 48 and 51 . These samples exhibited primarily brittle fracture failure.

These waste form samples have been stored in shielded drums throughout the project. Waste form contact dose and in-drum measurements indicate that the samples experienced a total beta/ gamma dose of $0.57 \times 10^{6}$ to $3.11 \times 10^{6} \mathrm{rad}$. The dose caused serious degradation of the polyethylene sample containers, which were replaced with cardboard tubes during the FY-91 test operation to preserve sample identity.

\section{Compressive Strength Results}

A total of 20 waste form samples were aged in shielded drums to self-irradiate under storage conditions and then compressive-tested to failure in this study. Table 4 presents the results of that testing and also lists the radiation dose rates measured at contact for each sample just before being tested. These dose rate measurements were subject to a number of variables such as not including the beta radiation component in many cases. However, the use of dose rates helped to estimate sample exposure dose rates. It is noted that the minimum compressive strength observed for the 20 waste form samples listed in Table 4 is well above the 500-psi recommended minimum strength of cement waste forms per Appendix A of the BTP Revision 1. That included the VES sample strengths.

The tabulated data are plotted (Figure 52) as compressive strength verses age of waste form sample. Results of compressive testing of 16 ascast samples ( 1 month old) and 16 tested samples ( 2 years old) have been included with the four sets of aged data to establish an early-in-life data base (Reference 7, Table 3). Also shown are data from tests of 16 externally irradiated waste form samples, which provide compressive strengths that have been degraded by an end-oflife maximum expected dose of irradiation that a waste form would receive after 300 years of selfirradiation (Reference 7 and Table 3). These externally irradiated waste form data are located to the right of the true aging data and are to be 
Table 4. Compressive load test results and radiation dose rates of aged EPICOR-II resin waste form samples.

\begin{tabular}{|c|c|c|c|c|c|}
\hline \multicolumn{2}{|c|}{ Sample ${ }^{\mathrm{a}}$} & \multirow{2}{*}{$\begin{array}{c}\text { Measured radiation } \\
\text { dose rate at contact } \\
(\mathrm{R} / \mathrm{hr})\end{array}$} & \multirow{2}{*}{$\begin{array}{l}\text { Sample } \\
\text { area } \\
\left(\text { in. }^{2}\right)\end{array}$} & \multirow[b]{2}{*}{$\begin{array}{c}\text { Ultimate load } \\
\text { (lb) }\end{array}$} & \multirow{2}{*}{$\begin{array}{c}\text { Compressive } \\
\text { strength } \\
\text { (psi) }\end{array}$} \\
\hline Number & $\begin{array}{l}\text { Age } \\
(\mathrm{yr})\end{array}$ & & & & \\
\hline C1-23 & 7 & $7^{b}$ & 2.70 & 9,890 & 3,670 \\
\hline $\mathrm{C} 2 \mathrm{~A}-7$ & 7 & $12^{b}$ & 2.65 & 17,000 & 6,405 \\
\hline D1A-2 & 7 & $25^{b}$ & 2.63 & 8,830 & 3,365 \\
\hline D2-27 & 7 & $28^{b}$ & 2.61 & 11,290 & 4,335 \\
\hline $\mathrm{C} 1-26$ & 8 & $5^{c}$ & 2.67 & 12,300 & 4,600 \\
\hline C $2 A-6$ & 8 & $7^{\mathfrak{c}}$ & 2.68 & 5,640 & 2,105 \\
\hline D1A-1 & 8 & $7^{\mathrm{c}}$ & 2.58 & 10,800 & 4,190 \\
\hline D2-35 & 8 & $8^{c}$ & 2.59 & 13,050 & 5,040 \\
\hline C1-24 & 11 & $4.5^{c}$ & 2.68 & 12,750 & 4,765 \\
\hline $\mathrm{C} 2 \mathrm{~A}-14$ & 11 & $6.5^{c}$ & 2.69 & 5,675 & 2,110 \\
\hline D1A-29 & 11 & $6.5^{\mathrm{c}}$ & 2.60 & 11,100 & 4,270 \\
\hline D2-34 & 11 & $7.5^{\mathrm{c}}$ & 2.59 & 10,450 & 4,035 \\
\hline $\begin{array}{l}\text { C1-31 } \\
\text { C1-35 }\end{array}$ & $\begin{array}{l}12 \\
12\end{array}$ & $\begin{array}{l}2^{b} \\
9^{b}\end{array}$ & $\begin{array}{l}2.68 \\
2.68\end{array}$ & $\begin{array}{r}16,950 \\
12,650 \\
\text { Average }\end{array}$ & $\begin{array}{l}6,335 \\
4,720 \\
5,525\end{array}$ \\
\hline $\begin{array}{l}\text { C2A-10 } \\
\text { C2A-29 }\end{array}$ & $\begin{array}{l}12 \\
12\end{array}$ & $\begin{array}{l}12^{b} \\
12^{b}\end{array}$ & $\begin{array}{l}2.69 \\
2.63\end{array}$ & $\begin{array}{r}14,250 \\
15,500 \\
\text { Average }\end{array}$ & $\begin{array}{l}5,360 \\
5,895 \\
5,625\end{array}$ \\
\hline $\begin{array}{l}\text { D1-13 } \\
\text { D1-14 }\end{array}$ & $\begin{array}{l}12 \\
12\end{array}$ & $\begin{array}{l}9^{b} \\
7^{b}\end{array}$ & $\begin{array}{l}2.60 \\
2.57\end{array}$ & $\begin{array}{r}8,550 \\
9,875 \\
\text { Average }\end{array}$ & $\begin{array}{l}3,290 \\
3,840 \\
3,565\end{array}$ \\
\hline $\begin{array}{l}\text { D2-1 } \\
\text { D2-12 }\end{array}$ & $\begin{array}{l}12 \\
12\end{array}$ & $\begin{array}{l}30^{b} / 12^{c} \\
30^{b} / 12^{c}\end{array}$ & $\begin{array}{l}2.55 \\
2.54\end{array}$ & $\begin{array}{r}9,250 \\
8,925 \\
\text { Average }\end{array}$ & $\begin{array}{l}3,630 \\
3,520 \\
3,575\end{array}$ \\
\hline
\end{tabular}


Description of Aging Test Results

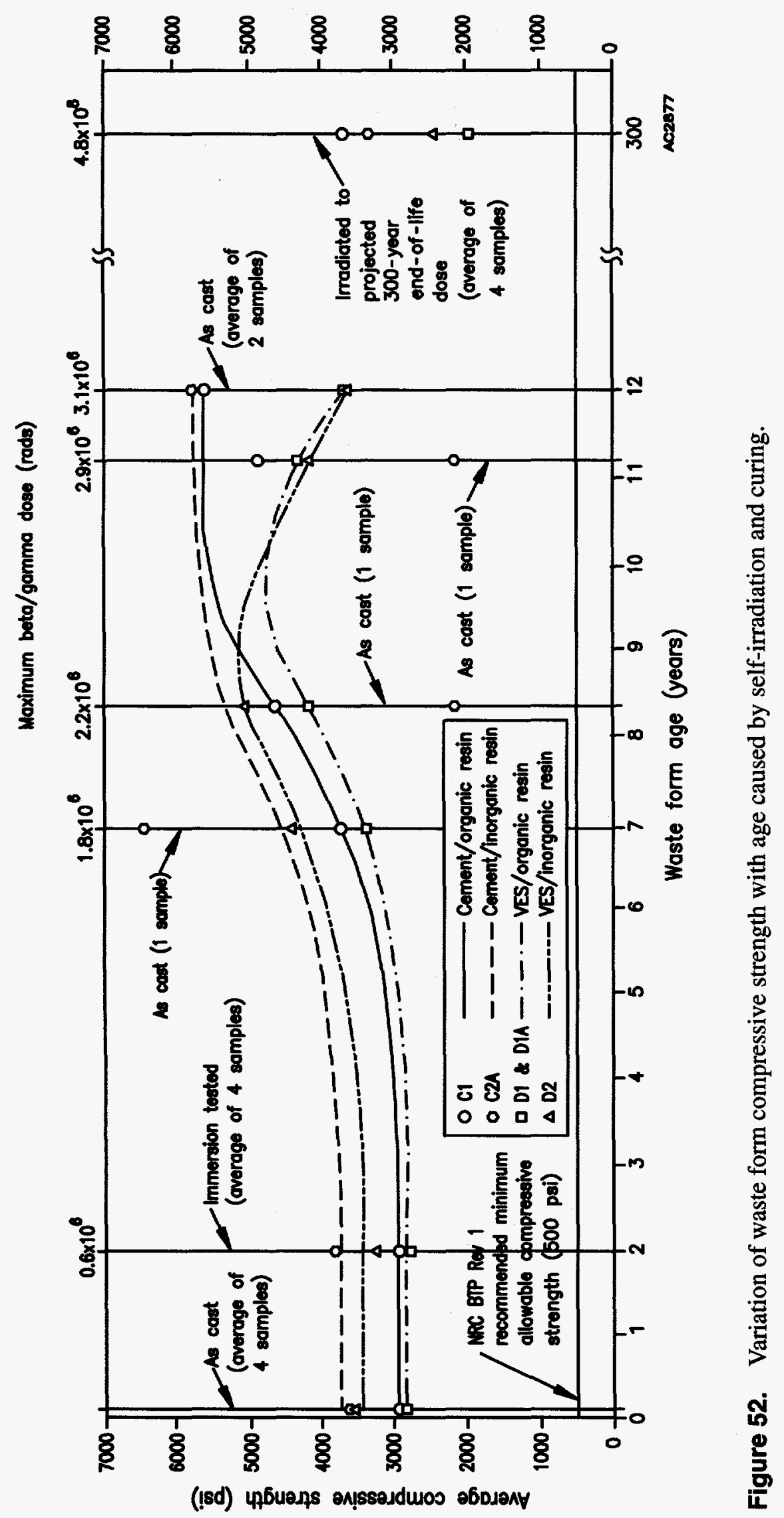


used as reference. They show conservative worstcase compressive strengths since a higher-thanexpected dose rate was used to irradiate the samples to the expected 300-year dose in less than 30 days. The 500-psi minimum recommended compressive strength is indicated across the width of Figure 52. All data are well above this value.

At age 7 years, all sample types exhibited increased compressive strengths with age. The cement sample containing organic/inorganic ionexchange resins exhibited an unusually high strength. It is noted that only one sample of each of the four types was tested. After 8 years, three of the sample types experienced continued increase in strength with age. The cement sample containing organic/inorganic ion-exchange resins exhibited an unusually low strength after being unusually high after 7 years. Note that again only one sample of each of the four types was tested. Three of the four sample types experienced little change in strength at age 11 years. The cement sample containing organic/inorganic ionexchange resins again exhibited an unusually low strength. The VES sample containing organic/ inorganic resins, which suffered brittle fracture, exhibited a drop in strength between 8 and 11 years. Again, only one sample of each of the four types was tested. The cement sample type containing organic resins experienced an increase in strength in the twelfth-year test. The strength of the cement samples containing organic/inorganic resins stabilized near the value of the organic resin sample in the twelfth year. The VES samples exhibited a drop in strength between 8 and 12 years, which was most pronounced in the twelfth-year test. Two samples of each of the four types were tested in the twelfth year. It appears that strength was affected by accumulated radiation dose after a steady increase of strength with age to 8 years for all four sample types.

One portland cement sample, C2A-6, failed far below the expected strength at 8 years, and C2A-14 showed comparable low strength at 11 years. However, the average strength of C2A-10 and C2A-29 in FY-95 (12 years) was at the expected value. It is anticipated that the cement samples would retain strength to a higher radiation dose than VES because low-level radi- ation is not known to adversely affect cement strength. The low strength exhibited by the cement samples containing organic/inorganic resin may have been caused by radiation effects on the contained organic constituent of the ionexchange resin, which serves as aggregate to the cement. However, that phenomenon would have been more likely to adversely affect the allorganic resin. That was not the case. It is noted that this same cement waste form type (C2A-7) exhibited an abnormally high strength at 7 years. An examination of the data from Reference 6 revealed that the cement batches contained waste form samples that were uniform in weight and radiation dose, while the VES batches contained some less uniform waste form samples. However, many of the cement waste form samples exhibited surface blemishes in the form of air bubbles. It is suspected that air bubbles were also contained within the interior of those cement waste form samples. Such discontinuities would detrimentally affect strength of those brittle waste form samples and are thought to be the cause of the observed compressive strength variations.

The cement compressive strength demonstrates the impact of data scatter, resulting from employing only one waste form sample of each type in several test years. In order to economize the few acceptable remaining waste form samples, only four were normally tested during each period, one of each type. Thus, one waste form sample with no imperfections and containing abnormal amounts of either zeolite aggregate or cement could have caused an unusually high compressive strength. Also, a waste form sample containing an interior flaw could produce nonrepresentative low strength. Due to the high radiation dose, the failed waste form samples were not examined closely enough to locate specific initiators of failure. The results (shown in Figure 52) from 1 month (ascast) and 2 years (immersion-tested) are the average of four data points at each value, while the results at 12 years (as-cast) are the average of two data points. These results all appear to be very consistent. The data that are averages for multiple test samples are more reliable than those obtained using a single test sample.

A review of the externally irradiated waste form compressive test results (Reference 7) showed that cement sample strength after 
irradiation varied considerably. The strength of waste form samples containing all organic resins (C1) varied from 1,740 to $5,230 \mathrm{psi}$, averaging 3,640 psi with a standard deviation of 1,440 psi. Strength of waste form samples with organic/ inorganic resins (C2A) varied from 1,860 to $5,200 \mathrm{psi}$, averaging 3,310 psi with a standard deviation of 1,710 psi. Reference 7 noted that standard deviations for the portland cement waste form sample compressive strength data were large and that material effects induced by gamma radiation may have been responsible for that variation. It is noted that all of the compressive strength results from 8 and 11 years fall within the standard deviations of the original irradiated waste form tests. The organic $\mathrm{C} 1$ samples hold toward the upper limit, while the organic/inorganic C2 samples fall near the lower limit. It is also noted that the strength of sample C2A-7 tested in the seventh year at 6,404 psi was well above that standard deviation as were the average strengths of both cement types in the 12-year test results.

The VES compressive strength data in Figure 52 show a steady increase with age (and subsequent radiation dose) through 8 years for both organic and organic/inorganic resin waste form samples. At 11 years, the organic-resin-containing waste form sample, D1A-29, exhibited strength almost identical to the 8-year-old sample, D1A-1. The D1 sample tested at 12 years showed a significant decrease in average strength from the previous year (17\%). The end of increase in strength is thought to be the result of total radiation dose on these waste form samples. The 11-year-old waste form sample that contained organic/inorganic resins, D2-34, showed a $20 \%$ drop in strength from the 8-year-old test sample, D2-35, probably as a result of radiationinduced cross-linking of the VES polymer. That effect would result in a more brittle failure as experienced by D2-34. That same effect was observed in the average strength that the D2 samples exhibited during testing at 12 years of age, where a drop of $12 \%$ was seen. As would be expected, the strengths produced by the samples containing inorganic zeolite were generally higher than the all-organic samples. Zeolite is unaffected by low-level radiation.
The doses applied to the externally irradiated waste form samples of Reference 7 were two orders of magnitude higher than the estimated doses after 12 years. The resulting average compressive strength of those four externally irradiated waste form types is shown on the right of the true aging data in Figure 52 and represents the projected 300-year end-of-life strength of these materials. The true end-of-life strength may be somewhat different than that in the test irradiations since they were accomplished in less than 30 days. The higher dose rates in that test are likely to have caused accelerated degradation of material and resulted in lower-than-expected actual end-of-life compressive strengths. The irradiations were also higher in average total dose by $67 \%$ for portland cement and $19 \%$ for VES compared to the actual 300-year end-of-life calculated dose as shown in Table 5.

The curves that represent the compressive strength data are expected fits to the data. Because only one sample of each waste form type was tested in years 7,8 , and 11 , it would be inaccurate to assume that the curves presented in Figure 52 are exact representations of the compressive strength. The following is a detailed description of the construction of these curves. The data from the early testing of as-cast, immersion-tested, and externally irradiated samples were obtained from an average of four samples of each waste form type for each age. These data are considered reliable although it should be noted that ASTM C39 (Reference 13) requires testing 10 samples to determine average compressive strength due to expected variation in strengths between samples. The plot of the cement samples containing organic/ inorganic resins ( $\mathrm{C} 2 \mathrm{~A}$ ) was developed by use of the plots of the other three types of samples and the data from those early tests. The strength of the C2A-type samples was the highest of the fourtypes in those early tests, and it remained the highest at 7 years, when it was higher than any previously observed result. The curve of $\mathrm{C} 2 \mathrm{~A}$ was drawn parallel to the other curves at year 7 . The next year, the strength of the C2A sample dropped dramatically to a value near the end-of-life value. That was inconsistent with the results of the other three types of material. Therefore, it was disregarded (as was the high value at 7 years), and the C2A curve was 
Table 5. Calculated total beta/gamma self-irradiation 300-year end-of-life doses versus gamma external irradiation doses received by EPICOR-II waste form samples in the INEL Advanced Test Reactor gamma irradiation facility in 1985.

\begin{tabular}{llcc}
\hline & & \multicolumn{2}{c}{$\begin{array}{c}\text { Total dose } \\
\text { (rad) }\end{array}$} \\
\cline { 3 - 4 } Solidification agent & \multicolumn{1}{c}{ Waste type resin } & Calculated & Received \\
\cline { 3 - 4 } Portland cement & All organic & $3.38 \mathrm{E}+8$ & $4.9 \mathrm{E}+8$ \\
& Organic/inorganic & $2.85 \mathrm{E}+8$ & $5.3 \mathrm{E}+8$ \\
& Organic/inorganic & $2.85 \mathrm{E}+8$ & $5.4 \mathrm{E}+8$ \\
& All organic & $3.38 \mathrm{E}+8$ & $5.3 \mathrm{E}+8$ \\
\cline { 2 - 4 } VES & Average & $3.12 \mathrm{E}+8$ & $5.23 \mathrm{E}+8$ \\
& & & \\
& All organic & $4.22 \mathrm{E}+8$ & $2.8 \mathrm{E}+8$ \\
& Organic/inorganic & $3.56 \mathrm{E}+8$ & $3.9 \mathrm{E}+8$ \\
& Organic/inorganic & $4.22 \mathrm{E}+8$ & $4.9 \mathrm{E}+8$ \\
& All organic & $3.56 \mathrm{E}+8$ & $5.7 \mathrm{E}+8$ \\
\hline
\end{tabular}

again assumed to be higher and parallel with the other sample curves. At 11 years, the strength of the single C2A sample was again very low, and both VES samples began to show a loss of strength with an increase in dose. The location and slope of both cement sample strength curves at 11 years could not be determined without more information. That was furnished by the test results of year 12, which are averages of two samples of each type. The strengths of the C2A samples were similar with a standard deviation of 378 psi. The strengths of the $\mathrm{C} 1$ samples were more diverse with a standard deviation of 1,142 psi. The averages of these data were only $100 \mathrm{psi}$ apart. The curves of both cement sample types were estimated between the data of 7 and 12 years. Because of the lack of data in that interval, it is possible that those curves do not accurately represent the actual waste form sample strengths. Those strengths could have peaked at up to 1,000 psi higher than indicated by the curves, but it is doubtful that they could have been as much as 200 psi less than shown. The highest cement sample strengths are thought to be those at 12 years. While the VES data show good correlation from year to year, predicting regular, smooth curves, it is not possible to determine the magnitude or location of the peak strength for these materials (that apparently occurred between 8 and 11 years) due to lack of data.

Although the limited number of samples tested prevents precise prediction of the compressive strength with age, it does permit the prediction of relative strengths and trends. The behavior illustrated in Figure 52 is one of high strengths for all waste form types after fabrication and curing. Compressive strengths then increase with age and self-irradiation dose over about 8 years for VES samples and 12 years for cement samples. Subsequently, based on 11- and 12-year data and externally irradiated waste form sample test results, compressive strength will decrease to the 300-year end-of-life strength shown in the figure.

It is again noted that the minimum compressive strength observed in these aging tests was 2,105 psi from sample C2A-6 at 8 years. This value is over four times the minimum recommended compressive strength of 500 psi for cement waste forms from Appendix $A$ of the BTP Revision 1. The minimum strength observed in the externally irradiated waste form sample testing was 1,740 psi for sample C1A-5, ${ }^{7}$ over three times the 500-psi minimum. The lowest value for a VES sample was 1,230 psi for sample D2-22, ${ }^{7}$ over 20 times the 60 -psi minimum for 
non-cement waste forms. These values clearly show that, while the compressive strength of prudently formulated VES and cement-solidified waste forms containing ion-exchange resins is degraded by self-irradiation over long periods of time, the resulting end-of-life strength will remain substantially above the minimums recommended by the NRC BTP Revision 1. 


\section{CONCLUSIONS}

Both cement waste form types exhibited an increase in strength with age and self-irradiation dose over the 12 years of this study. After a buildup over the first 8 years, that increase seemed to have stabilized at about 5,500 psi for both cement types. In the interval from 7 through 11 years, the cemented organic/inorganic resin waste form sample data were scattered very high and low. However, the cemented all-organic resin waste samples exhibited more consistent results, with one low point at 11 years. Comparing these data to the externally irradiated compressive strength data obtained in 1985 indicates that the strength of the cemented wastes will slowly decrease with further age to about 3,000 psi after 300 years as predicted by end-of-life testing. This value is well above the 500-psi minimum recommended by the BTP Revision 1 .

Both VES waste form types also exhibited an increase in strength with age and self-irradiation dose through 8 years. The maximum strength of the VES samples was between 4,500 and 5,000 psi. At 11 years, strength had significantly decreased with the organic/inorganic resin waste form sample (20\%). At 12 years, both types of waste form samples suffered a further strength decrease (16\% for all-organic and $11 \%$ for organic/inorganic resin wastes). Comparing these data to those of the externally irradiated end-oflife test compressive strength data obtained in 1985 confirms that the VES sample strength will continue to decrease with age to about 2,000 psi. This value is also well above the 60-psi minimum required for VES by the BTP Revision 1.

The total beta/gamma exposure dose experienced by the 12-year-old waste form samples was between $0.6 \times 10^{6}$ and $3.1 \times 10^{6} \mathrm{rad}$. That is two orders of magnitude less than the 300-year end-of-life doses received by the externally irradiated samples of earlier INEL tests, and these aged samples had not reached the low strength exhibited by those earlier externally irradiated samples.

This study reaffirmed the advisability of testing multiple samples of the same type to reduce the impact of data scatter. Because four related waste form types were examined here, the use of one or two samples still provided useful information. A study period of several more years could have produced a complete strength-to-age curve for the VES waste form samples; however, it is probable that the cemented waste sample strength would have remained unchanged for many years. 



\section{REFERENCES}

1. R. C. Schmitt and H. W. Reno, Program Plan of the EPICOR and Waste Research and Disposition Program of the Technical Support Branch, EGG-TMI-6521, revised December 1983.

2. J. W. McConnell, Jr, EPICOR-II Resin/Liner Research Plan, EGG-TMI-6198, March 1983.

3. Code of Federal Regulations, 10 CFR 61, "Licensing Requirements for Land Disposal of Radioactive Wastes," Office of the Federal Register, December 1982.

4. U.S. Nuclear Regulatory Commission, "Technical Position on Waste Form," Low-Level Waste Management Branch, Washington, D.C., May 1983.

5. U.S. Nuclear Regulatory Commission, "Technical Position on Waste Form," Revision 1, Low-Level Waste Management Branch, Washington, D.C., January 1991.

6. R. M. Neilson, Jr. and J. W. McConnell, Jr., Solidification of EPICOR-II Resin Waste Forms, GENDINF-055, August 1984.

7. R. M. Neilson, Jr. and J. W. McConnell, Jr., EPICOR-II Resin Waste Form Testing, NUREG/CR-4637, EGG-2457, October 1986.

8. R. D. Rogers and J. W. McConnell, Jr., Biodegradation Testing of TMI-2 EPICOR-II Waste Forms, NUREG/CR-5137, EGG-2450, June 1988.

9. R. D. Rogers, J. W. McConnell, Jr., E. C. Davis, and J. D. Jastrow, Annual Report of the TMI-2 EPICOR-II Resin/Liner Investigation: Low-Level Waste Data Base Development Program for Fiscal Year 1988, NUREG/CR-5229, Vol. 1, EGG-2553, December 1988.

10. J. W. McConnell, Jr., R. D. Rogers, D. A. Johnson, J. D. Jastrow, and D. S. Wickliff, Annual Report of the Field Lysimeter Investigations: Low-Level Waste Data Base Development Program for Fiscal Year 1990, NUREG/CR-5229, EGG-2577, Vol. 3, Idaho National Engineering Laboratory, EG\&G Idaho, Inc., December 1990.

11. J. W. McConnell, Jr., R. D. Rogers, J. D. Jastrow, and D. S. Wickliff, Annual Report of the Field Lysimeter Investigations: Low-Level Waste Data Base Development Program for Fiscal Year 1992, NUREG/CR-5229, EGG-2577, Vol. 5, Idaho National Engineering Laboratory, EG\&G Idaho, Inc., February 1993.

12. J. W. McConnell, Jr., R. D. Rogers, J. D. Jastrow, W. E. Sanford, T. M. Sullivan, Annual Report of the Field Lysimeter Investigations: Low-Level Waste Data Base Development Program for Fiscal Year 1994, NUREG/CR-5229, INEL-94/0278, Vol. 7, May 1995.

13. American Society for Testing and Materials, ASTM C39, "Standard Test Method for Compressive Strength of Cylindrical Concrete Samples," 1972.

14. American Society for Testing and Materials, ASTM C617, "Standard Method of Capping Cylindrical Concrete Samples," 1976. 


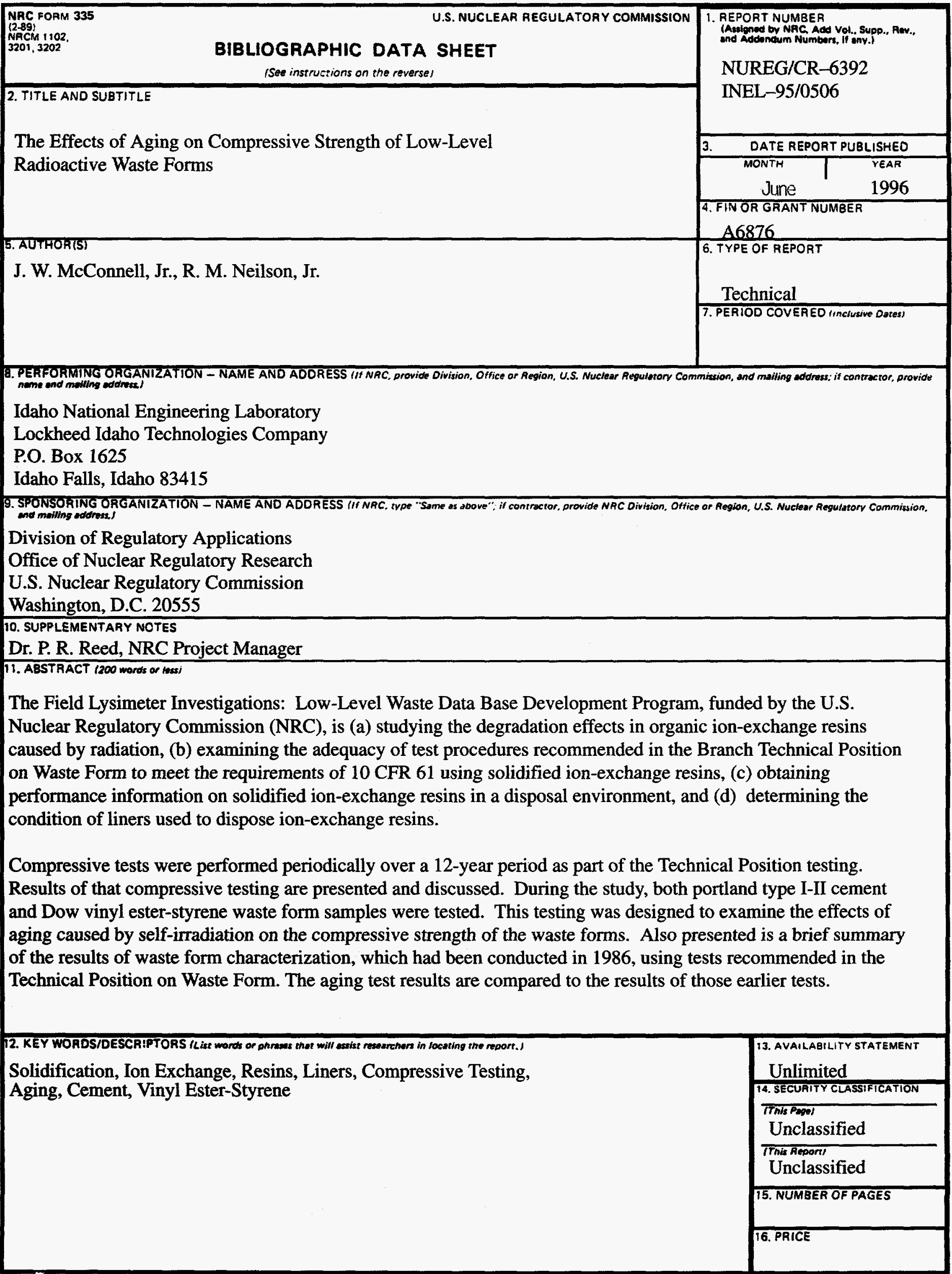

